\title{
Tree Biomass Estimation in Central African Forests Using Allometric Models
}

\author{
Romeo Ekoungoulou ${ }^{1}$, Donatien Nzala ${ }^{2}$, Xiaodong Liu ${ }^{1}$, Shukui Niu1 ${ }^{*}$ \\ ${ }^{1}$ Laboratory of Ecosystems Management and Planning, College of Forestry, Beijing Forestry University, Beijing, China \\ ${ }^{2}$ Département des Techniques Forestières, Ecole Nationale Supérieure d'Agronomie et de Foresterie, Université Marien Ngouabi, \\ Brazzaville, Republic of Congo \\ Email: ^niushukui@yahoo.com, ^xd_liu@bjfu.edu.cn
}

How to cite this paper: Ekoungoulou, R., Nzala, D., Liu, X.D. and Niu, S.K. (2018) Tree Biomass Estimation in Central African Forests Using Allometric Models. Open Journal of Ecology, 8, 209-237. https://doi.org/10.4236/oje.2018.83014

Received: September 30, 2017

Accepted: March 27, 2018

Published: March 30, 2018

Copyright (c) 2018 by authors and Scientific Research Publishing Inc. This work is licensed under the Creative Commons Attribution International License (CC BY 4.0).

http://creativecommons.org/licenses/by/4.0/

\section{cc) (i) Open Access}

\begin{abstract}
Quantifying the tropical forests' carbon stocks is presently an important component in the implementation of the emerging carbon credit market mechanisms. This calls for appropriate allometric equations predicting biomass which currently are scarce. In this study, we aimed to estimate above- and below-ground biomass and carbon stocks of trees, and to identify the variation in diameter-height allometry of Ipendja mixed terra firme lowland tropical forest's trees. The study area is located at Ipendja forest management unit (UFA), close to Dongou district (Likouala Department), in Northern Republic of Congo. This study combined forest inventory data of 1340 trees recorded from eight studied plots distributed in two sites, respectively Mokelimwaekili (i.e., Old-growth forest) and Sombo (i.e., Selective logging forest). Trees measurements were done with rectangular plots, each $25 \times 200 \mathrm{~m}$ (i.e., 0.5 ha, $5000 \mathrm{~m}^{2}$ ). In eight studied plots (4 plots per site), only trees with $\mathrm{DBH} \geq 10$ $\mathrm{cm}$ were measured and identified. 1340 trees founded were belonged 145 species and 36 botanical families ( $n=733$ and $n=607$, for Sombo and Mokelimwaekili respectively). The analyses were conducted using allometric method for aboveground biomass (AGB) and belowground biomass (BGB) estimations. The results showed that in Ipendja forest ecosystem the mean biomass is built up for AGB (346 Mg.ha ${ }^{-1}$ ) as well as for BGB (81.3 Mg.ha $\left.{ }^{-1}\right)$, with a significant difference between forest types $(F=23.46, \mathrm{df}=7.771, P=0.001)$. It was obvious that biomasses in Mokelimwaekili (AGB: $559.7 \mathrm{Mg} \cdot \mathrm{ha}^{-1}$, BGB: $131 \mathrm{Mg} \cdot \mathrm{ha}^{-1}$ ) were higher than those of Sombo (AGB: $291.8 \mathrm{Mg} \cdot \mathrm{ha}^{-1}$, BGB: $\left.68.5 \mathrm{Mg} \cdot \mathrm{ha}^{-1}\right)$. By this study, Ipendja forest ecosystem has clearly variations on the diameter-height relationship and biomass across the plots and the sites.
\end{abstract}

\section{Keywords}

Aboveground Biomass, Allometry, Belowground Biomass, Ipendja, 
Mokelimwaekili, Sombo

\section{Introduction}

The importance of forests in carbon (C) cycling has gained increasing attention in recent years. With the current interest in greenhouse gas emissions and their impact on global climate change, accurate, precise, and verifiable estimation of carbon stocks in forests have become insistently required [1]. Accurate estimation of tropical tree biomass is essential to determine geographic patterns in carbon stocks, the magnitudes of fluxes due to land-use change, and to quantify avoided carbon emissions via mechanisms such as (REDD+) Reducing emissions from deforestation, forest degradation, and forest conservation, sustainable management of forest, and enhancement of forest carbon stocks [2]-[12]. While there has been much debate and exploration of the analytical methods for calculating biomass, the methods used to determine rates of wood production have not been evaluated to the same degree [13] [14] [15] [16]. This affects assessment of ecosystem fluxes and may have wider implications if inventory data are used to parameterize biosphere models, or scaled to large areas in carbon sequestration assessment [17]. Tropical forests are highly diverse ecosystems that play a key role in the global carbon cycle [1] [8] [18] [19] [20] [21]. A considerable amount of data on aboveground biomass (AGB) stored in alive trees in lowland tropical forests, and the factors affecting it, have become available in the past few years [1] [22] [23].

[3] proposed a scheme where different allometric models should be used depending on vegetation type and on the availability of total tree height information. As a compromise between environmental variation and data availability at the time, [3] proposed a classification of tropical forests into three forest types, dry, moist, and wet, following the hold ridge life zone system [8] [18]. To estimate live tree biomass, diameters of all trees are measured and converted to biomass and carbon estimates (carbon $=50 \%$ of biomass) generally using allometric biomass regression equations [2] [3] [10] [24] [25] [26]. Global trees carbon estimations in tropical forests varies between $40 \%$ and $50 \%$ of the total biomass in terrestrial vegetation, indicating considerable uncertainty [8] [10] [26] [27]. Such uncertainty is the consequence of linking individual tree measurements to largescale patterns of carbon distribution, as well as the definition as to what constitutes "forest".

Aboveground biomass (AGB) of forests can be estimated from ground-based inventory plots, where allometric equations are used to estimate AGB from measured tree diameters [18]. Tree height is an important component of this allometric relationship, as tree biomass is partially a function of tree volume, which is, in turn, a function of tree height [20], trunk basal area and trunk taper [28]. Incorporating a height parameter is known to markedly improve estima- 
tion of individual tree AGB [8], and this has a substantial effect at larger scales too.

One of the approach used to develop biomass models involved destructive sampling of trees [26]. This approach does not seem appropriate in the current context of using forests to mitigate climate change, as it releases an important amount of carbon to the atmosphere [29] [30]. Also, it does not protect threatened species in forest ecosystems. Furthermore, biomass models are to be consistent with allometric scaling laws which suggest that the size influences nearly all of the structural, functional and ecological characteristics of organisms and that the tree characteristics, including diameter and height, would be good predictors of tree volume and biomass [30] [31]. Allometric equations are statistical models that predict the biomass of a tree from other dendrometrical characteristics (i.e. diameter, height, wood density) that are easier to measure and non-destructive [12]. Several authors have highlighted that current knowledge on allometric models in tropical rainforests needs improvement to get precise and accurate estimates of carbon stocks [2] [11] [23] [32].

Accurate estimation of forest ecosystem biomass needs reliable regression equations which can convert tree variables measured directly in the field, such as diameter and height, to aboveground biomass estimation. Up to 2010, only a few studies had been developed specifically to estimate with the contribution of African tropical forests biomass [32] [33]. These studies were either less precise or developed with very few trees sampled destructively which limited the use of these allometric relations to a wider range of ecosystems. Therefore, general allometric equations also known as pantropical allometric models [3] [28] have been widely used in Africa to assess biomass and carbon stocks [1], leading to the question about the reliability of estimates using these equations [11] [32]. The lack of models calibrated using data from Africa has recently been addressed by a range of studies on site-specific allometric equations [4] [5] [11] [29] [32] [34]. In [18], it was suggested that significant effect of forest type in [28] was due to the fact that Dry and Wet forests were represented by few sites and few trees in comparison to the moist type.

Above- and below-ground biomasses are important components of terrestrial ecosystem carbon stocks. Patterns of aboveground biomass distribution in terrestrial ecosystems are reasonably well understood, whereas knowledge of belowground biomass and its distribution is still quite limited [35]. This disparity in knowledge is essentially because of methodological difficulties associated with observing and measuring root biomass [3] [35]. Knowledge of root biomass dynamics is fundamental to improving our understanding of carbon allocation and storage in terrestrial ecosystems [24] [35]. However, the distribution of the dataset in all the strata of tropical moist forests in Africa is also questionable [36] and these allometric equations could be used in the absence of locally developed allometric equations or in association [37].

The present study about the carbon stocks of forest biomass in the northern 
Republic of Congo, will allow us to estimate the carbon stocks in forest ecosystems of the Likouala Department (Northern Republic of Congo) using Allometric equations. The results of this study will be useful to the Republic of Congo's national forest carbon quantification program, managed by the CN-REDD+ Congo Project, and the Republic of Congo's Ministry of Forest Economy and Sustainable Development. The objectives of this study were to: 1) estimate above- and below-ground biomass and carbon stocks of trees in Ipendja evergreen forest using allometric equations; 2) compare carbon stocks between old-growth and selective logging forests, respectively Mokelimwaekili and Sombo; 3) assess the diameter-height relationship of trees in Ipendja mixed evergreen lowland forest.

\section{Materials and Methods}

\subsection{Study Sites}

The sites were located in northern Republic of Congo, in Likouala Department, close to Impfondo city and Dongou district [36]. The study was conducted in the Ipendja $\left(2^{\circ} 32^{\prime} \mathrm{N}, 17^{\circ} 20^{\prime} \mathrm{E}\right.$, Figure 1$)$ forest management unit (UFA) managed by Thanry-Congo logging company (STC). The study was divided into two sites, such as Mokelimwaekili (Figure 1(a)) and Sombo (Figure 1(b)) respectively site1 and site2. With an area of 461 thousand hectares, the Ipendja forest management unit (UFA) is in the shape of trapezoidal, it was name Ipendja because it is crossed by the Ipendja river and it is limited by Motaba to the southwest and Ibenga to the northeast. The northwestern and southeastern boundaries are perpendicular to these rivers.

\subsection{Climate}

The Republic of Congo's climate is characterized by heavy precipitation and high temperature and humidity. The equator crosses the country just in north part, precisely at Makoua city in the Cuvette centrale Department. In the north a dry season extends from November through March and rainy season from April through October, whereas in the south the reverse is true [38]. On both side of the Equator, however, local climate exist with two dry and two wet seasons. Annual precipitation is abundant throughout the country, but seasonal and regional variations are important. Precipitation averages more than 48 inches $(1200 \mathrm{~mm})$ annually but often surpasses 80 inches $(2000 \mathrm{~mm}$ ) (Figure 2). Temperatures are relatively stable, with little variation between seasons. More variation occurs between day and night, when the difference between the highs and lows averages about $27^{\circ} \mathrm{F}\left(15^{\circ} \mathrm{C}\right)$. Over most of the country, annual average temperature range between the high $60 \mathrm{~s}$ and low $80 \mathrm{~s} \mathrm{~F}$ (low and high $20 \mathrm{~s} \cdot{ }^{\circ} \mathrm{C}$ ), although in the south, the cooling effect of the Benguela current may produce temperatures as low as mid-50 s F (low $10 \mathrm{~s} .{ }^{\circ} \mathrm{C}$ ). The average daily humidity is about 80 percent.

However, the meteorological station that cover Ipendja is around Impfondo city, located about 60 kilometers of the southeast massif to be developed, shows 


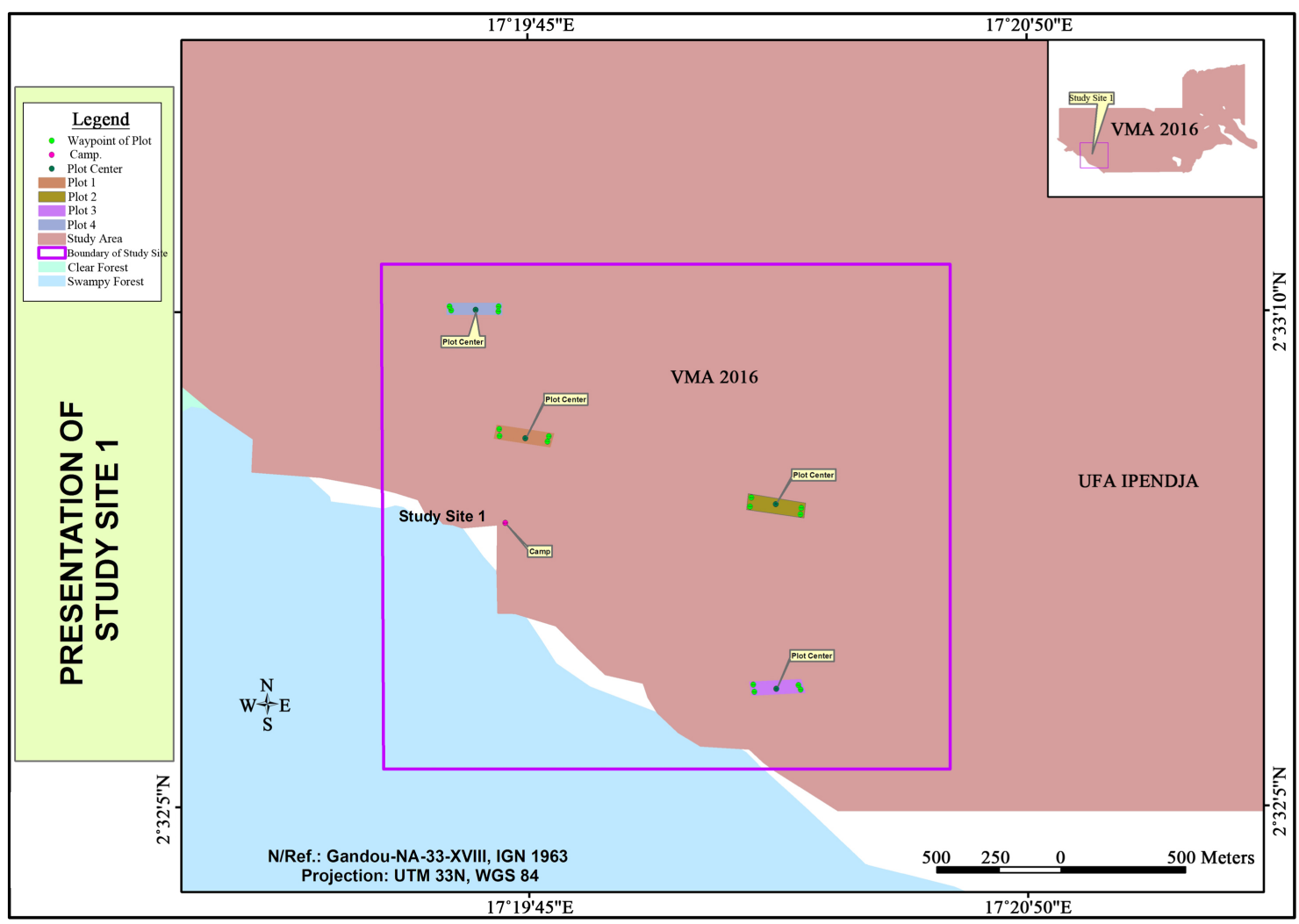

(a)

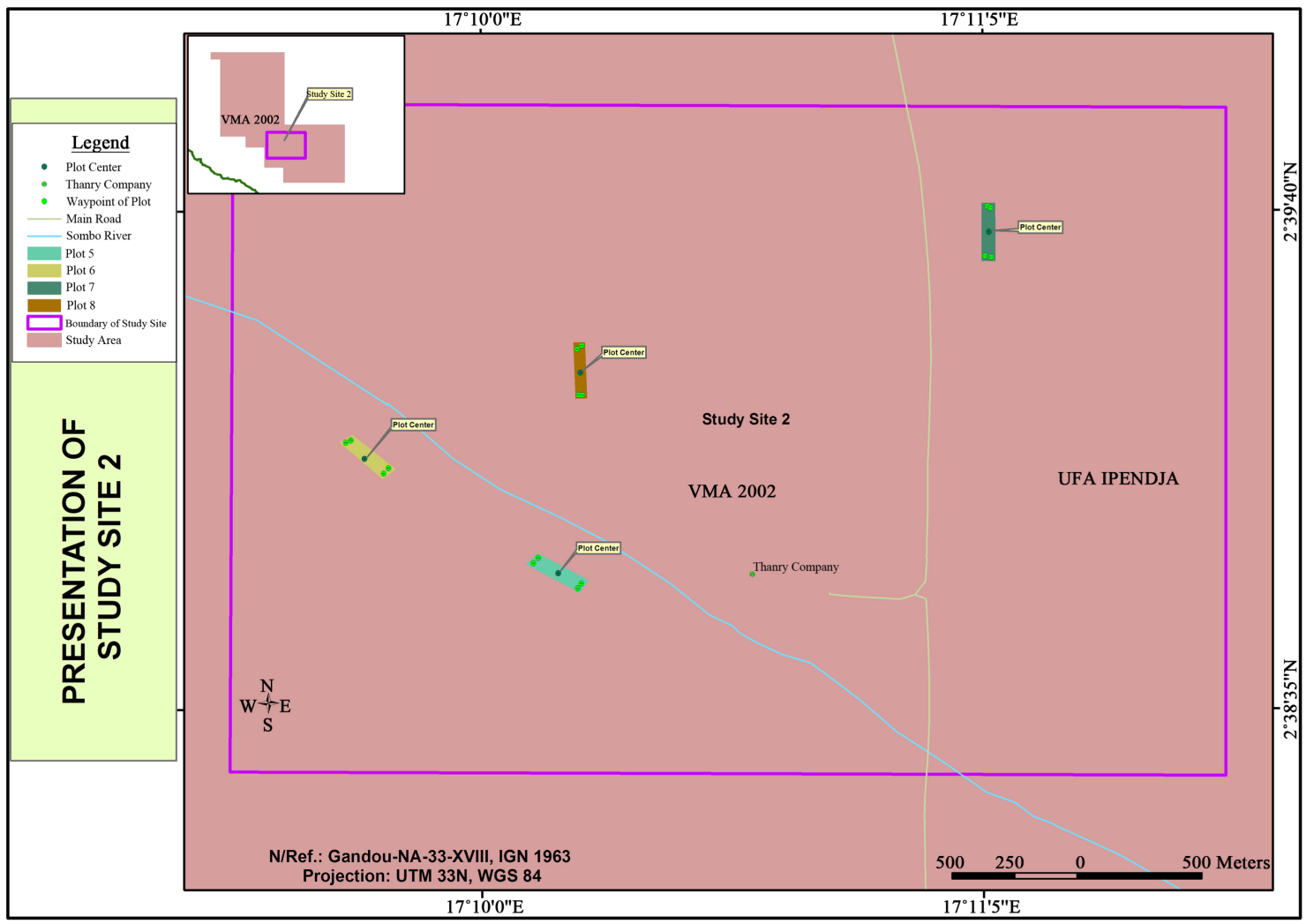

(b)

Figure 1. Study sites location: Mokelimwaekili (a) and Sombo (b) sites. 


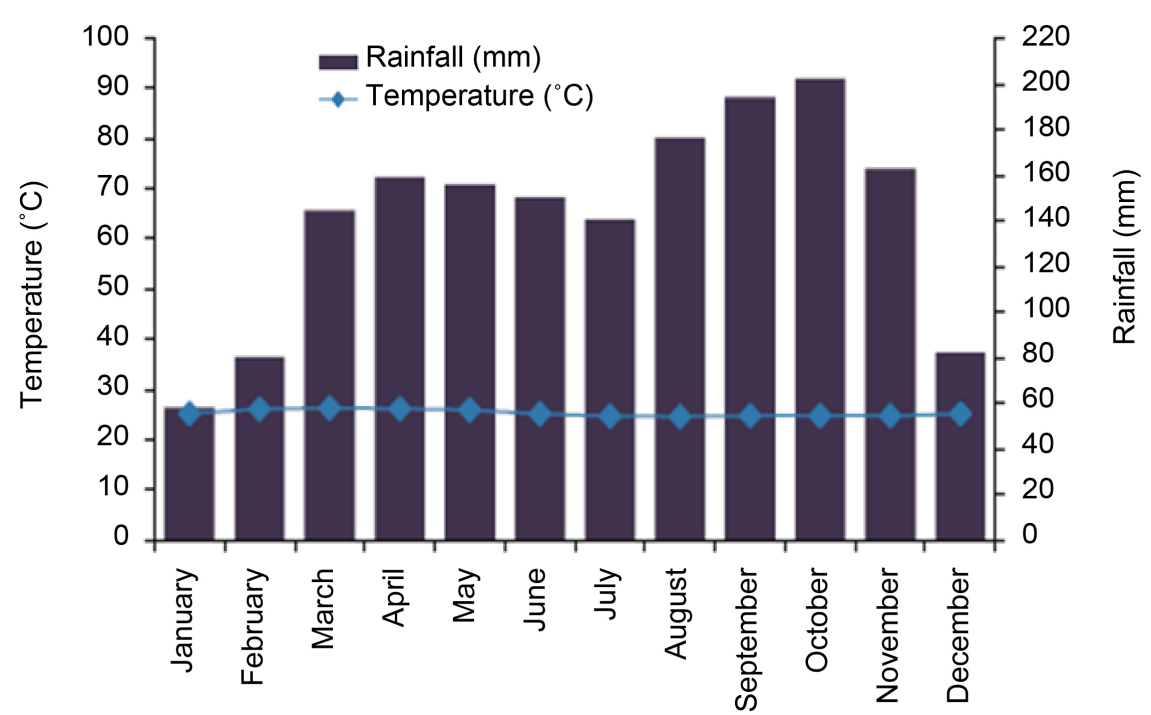

Figure 2. Climograph of the main meteorological station around the study area (average from 1978-2015).

that the dry season tends to move to the northeast [38]. The Ipendja forest management unit therefore undergoes an equatorial climate without a real dry season, with minimum rainfall in December, January and February $(<90 \mathrm{~mm})$ and maximum rainfall from August to November ( $>150 \mathrm{~mm}$ ), for an annual total of around $1600 \mathrm{~mm}$ (Figure 2). With amplitude ranging from $20^{\circ} \mathrm{C}$ to $30^{\circ} \mathrm{C}$, the average annual temperature is around $25^{\circ} \mathrm{C}$ (Figure 2).

\subsection{Forest Inventory Data}

Data collection was conducted using eight rectangular plots (Table 1), each 0.5 ha (i.e., $200 \times 25 \mathrm{~m}$ ). A double decameter has been used to measure the DBH (diameter at breast height) for each tree (only trees with $\mathrm{DBH} \geq 10 \mathrm{~cm}$ were measured) in all eight plots of study area. We excluded trees with $\mathrm{DBH}<10 \mathrm{~cm}$ [6] because such trees hold a small fraction of aboveground biomass in forest woodland, and would otherwise dominate the signal in regression models [18] [29] [37]. Wood specific gravity for each tree has been provided by Global Wood Density Database from DRYAD (Retrieved January 13, 2016 at https://doi.org/10.5061/dryad.234). In this study, the live biomass was aboveground biomass (AGB) and belowground biomass (BGB). Belowground biomass (BGB) was estimated from aboveground biomass [3] [24] [35]. The data to estimate aboveground biomass (AGB) of trees have been collected using the following parameters: diameter at breast height $\mathrm{DBH}(\mathrm{cm})$, wood specific gravity $\rho(\mathrm{g}$ $\mathrm{cm}^{-3}$ ) and total tree height $(\mathrm{m})$. Ipendja forest management unit (UFA) is a moist tropical evergreen lowland terra firme forest with a status of old-growth (Mokelimwaekili) and selective logging (Sombo) forests. The stems less than 10 $\mathrm{cm}$ would normally be measured in fairly young forest [1] [3].

We used a laser Hypsometer (Brand Nikon vision Co., Ltd., Forestry Pro No WJ072214) to measure the teller trees with a $\mathrm{DBH} \geq 10 \mathrm{~cm}$ each in the study 
Table 1. Characteristics of the study plots in Ipendja lowland terra firme forest. $n$ is the number of sampled trees by plot; DBH is average of diameter at breast height (in $\mathrm{cm}$ ) of trees measured using forestry meter tape; Height is average of trees height (in $\mathrm{m}$ ) per plot measured utilizing hypsometer; WSG is mean of wood specific gravity (in $\mathrm{g} \cdot \mathrm{cm}^{-3}$ ) values retrieved from the global wood density database at

http://datadryad.org/handle/10255/dryad.235 (Accessed January 13, 2016) ([39] [40]); AGB is aboveground biomass (in $\mathrm{Mg} \cdot \mathrm{ha}^{-1}$ ) calculated using the standard model for all tropical forests developed by [18]; BGB is belowground biomass (in $\mathrm{Mg}^{-h^{-1}}{ }^{\text {) calculated }}$ utilizing the model for tropical moist forests proposed by [35]; $\mathrm{G}$ is basal area (in $\mathrm{m}^{2} \cdot \mathrm{ha}^{-1}$ ) calculated for each plot according to ForestPlots (http://www.forestplots.net) and AfriTRON (http://www.afritron.org) protocols.

\begin{tabular}{lccccccccc}
\hline Plots & Site & $n$ & Species & DBH & Height & WSG & AGB & BGB & G \\
\hline Plot1 & Mokelimwaekili & 137 & 68 & 30.33 & 21.04 & 0.631 & 656.1 & 154.1 & 28.93 \\
Plot2 & Mokelimwaekili & 187 & 73 & 25.53 & 14.42 & 0.631 & 324.1 & 76.1 & 30.98 \\
Plot3 & Mokelimwaekili & 134 & 61 & 28.38 & 14.83 & 0.608 & 395 & 92.8 & 26.24 \\
Plot4 & Mokelimwaekili & 149 & 58 & 29.24 & 15.92 & 0.595 & 439.5 & 103.3 & 32.41 \\
Plot5 & Sombo & 171 & 64 & 25.51 & 12.22 & 0.596 & 260.5 & 61.2 & 23.48 \\
Plot6 & Sombo & 184 & 70 & 22.69 & 12.75 & 0.599 & 217.1 & 51 & 21.63 \\
Plot7 & Sombo & 189 & 66 & 25.01 & 13.42 & 0.604 & 278.4 & 65.4 & 27.45 \\
Plot8 & Sombo & 189 & 55 & 22.44 & 11.92 & 0.593 & 196.9 & 46.2 & 22.75 \\
\hline
\end{tabular}

plots. Tree height is a fundamental geometrical variable for trees. Unfortunately, most measures are based on visual inspection, and they are almost always considerably biased, as it is difficult to assess the size of vertical objects $10-40 \mathrm{~m}$ in height. One no-biased height estimate makes use of automated distance measurement tools, as reported here. We then used a compass (model SILVA-2S, Scale 1:24,000) to determine cardinal points (Nord-South and East-West) or orientations of each plot. The double tape decameter was used (model Stanley-30 m, serial number 34 - 108) made by Forestry Suppliers Inc, USA to measure the diameter at breast height (DBH) for each tree at both the Mokelimwaekili and Sombo forests. Finally, a Global positioning system (GPS) model Garmin 62CSx has been used to record the plot location (coordinates) in minutes, degrees and seconds. Latitude, longitude and altitude were then recorded using GPS in each plot center and four sides of all rectangular plots studied. Data from each plot were recorded.

However, the measurements have been performed by taking into account the tree locations. For trees with obstacles, we added $30 \mathrm{~cm}$ to $1.3 \mathrm{~m}$ (the normal size measurements). The description of the approach used to measure trees of the study was incorporated into the data collection to allow measurements to be made with precision and accuracy. The following steps have been done: An enumerator responsible for recording data has been focused exclusively on measuring and marking trees. Registration took place at the center of the plot being measured. The enumerator also monitored those measuring trees and en- 
sured no trees were omitted; to prevent double counting or omission of trees, the measurement start from north and the first tree was labeled. Any measured tree was immediately labeled with a permanent marker sign facing the center of the plot to allow the data enumerator to distinguish between measured and unmeasured trees; any tree of suitable size inside each nested plot has a numbered tag, preferably was the polyvinyl chloride plastic, and nailed to it. However, all trees positioned in the plot boundary at trunk diameter $>50 \%$ out of plot were excluded (not measured). Field inventory has been performed with accordance to forest plots (see http://www.forestplots.net) protocol [37], and the African tropical rainforest observation network protocol (AfriTRON), which is an international network of researchers engaged in on-the-ground long-term monitoring of tropical forests (see http://www.afritron.org). Climate data has been provided by National Agency of Congo's Civil Aviation [38].

\subsection{Data Analysis}

\subsubsection{Trees Processing Overview}

Once a fieldwork campaign is finished, the data has been digitized in spreadsheets according to standard procedures outlined in the data organization section [37]. The general checklist of species composing the flora procession has been established after digital processing of eight sample plots, on the basis of The African plants database (v.3.4.0) of Conservatory and Botanical Garden of Geneva, Switzerland and South African National Biodiversity Institute, Pretoria (Accessed 20 October 2016 at

http://www.ville-ge.ch/musinfo/bd/cjb/africa/recherche.php), The Global plants database (Accessed January 10, 2017 at http://plants.jstor.org), The working list of all plant species database (Retrieved 16 February 2017 from

http://www.theplantlist.org), and The Xycol database (The list of scientific and vernacular woods names: Accessed October 26, 2016 at

http://www.xycol.net/index.php? categorie=0\&sess_langue=430). All trees have been also checked and confirmed by The Missouri botanical garden's herbarium database, which is the one of world's outstanding research resources for specimens and information on plants (see http://www.missouribotanicalgarden.org). The variation of biomass stock within and between vegetation types was analyzed and correlated with parameters including tree density, basal area and stem height. Density refers to the average number of trees per plot and basal area is the sum of the cross-sectional area at $1.3 \mathrm{~m}$ above the ground level of all trees in a plot [37]. In order to perform this analysis, all data (diameter at breast height, stem density and tree height) were distributed in eight studied rectangular plots of Ipendja terra firme tropical forest ecosystem.

To estimate biomass and carbon stock in Ipendja forest, allometric methods from [18] and from [35] have been used by biomass calculation. The reason for choosing the allometry method is according to the recommendation of REDD+ initiatives, also to contribute in the global climate change mitigation as men- 
tioned in intergovernmental panel on climate change guidelines [9]. The methodology used was the nondestructive technic and the calculations were done by the allometric equation from [8] (1) to calculate the aboveground biomass (AGB). The model from [35] has been used to calculate the belowground biomass (BGB).

- Total aboveground biomass (AGB) of each tree in the plots has been estimated using the following allometric model from [18]:

$$
\mathrm{AGB}_{\text {est }}=0.0673 \times\left(\rho D^{2} H\right)^{0.976}
$$

$\rho=\operatorname{wood}$ density $\left(\mathrm{g} \cdot \mathrm{cm}^{-3}\right)$,

$D=$ diameter at breast height $(\mathrm{cm})$,

$H=$ height of tree $(\mathrm{m})$,

$\mathrm{AGB}=$ aboveground biomass $\left(\mathrm{Mg} \cdot \mathrm{ha}^{-1}\right)$.

Aboveground biomass (AGB) of trees for each permanent rectangular sample plot was calculated from a combination of variables [8]. Wood density $(\rho)$ was extracted from a global wood density database

(http://datadryad.org/handle/10255/dryad.235: Retrieved January 13, 2016; [39] [40]). Wood density $(\rho)$ is an important predictive variable in all regressions model to estimate trees biomass [6]. The pantropical allometric model proposed by [18] has been fitted to log-transformed data using ordinary least-squares regression:

$$
\ln (\mathrm{AGB})=\alpha+\beta \times \ln \left(H \times D^{2} \times \rho\right)+\varepsilon
$$

With AGB (in $\mathrm{Mg} \cdot \mathrm{ha}^{-1}$ ) representing the aboveground tree biomass, $\alpha$ and $\beta$ are the model coefficients (derived from least-squares regression), $D$ (in $\mathrm{cm}$ ) the tree trunk diameter, $H$ (in $\mathrm{m}$ ) the total tree height, $\rho$ (in $\mathrm{g} \cdot \mathrm{cm}^{-3}$ ) the wood specific gravity and $\varepsilon$ (epsilon) the error term, which is assumed to follow a normal distribution $\mathrm{N}\left(0, \mathrm{RSE}^{2}\right)$, where RSE is the residual standard error of the model. This model, denoted by $m_{0}$, was considered as the reference model [15].

- Next, to estimate belowground biomass (BGB), we used equation from [35]. The equation developed by [35] for moist tropical forest (i.e., the model can be founded in Table 2 of [35]) is as follows:

$$
\begin{gathered}
Y=0.205 \times \mathrm{AGB} \text { if } \mathrm{AGB} \leq 125 \mathrm{Mg} \cdot \mathrm{ha}^{-1} \\
Y=0.235 \times \mathrm{AGB} \text { if } \mathrm{AGB}>125 \mathrm{Mg} \cdot \mathrm{ha}^{-1}
\end{gathered}
$$

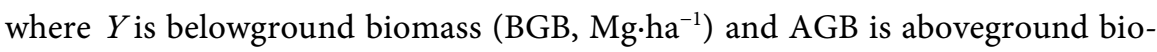

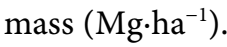

Therefore, Models developed by [18] [35] are now the standard models for measuring carbon stocks in tropical forests [23]. To estimate carbon stock, the biomass (above- and below-ground biomass) were devised by two to obtain the carbon for each plot [2]. Moreover, a carbon stock is typically derived from live or coarse woody debris (CWD) biomass by assuming that $50 \%$ of the biomass is made up carbon [2] [3] [24]. 
Table 2. Focal species distribution recorded in the Ipendja mixed lowland terra firme tropical forest ecosystem (old-growth without logging forest and selective logging forest, respectively in Mokelimwaekili and Sombo sites) by botanical family. Trees taxonomy was homogenized according to the African plants database (version 3.4.0) from Conservatory and botanical garden of Geneva, Switzerland and South African national biodiversity institute, Pretoria (accessed October 20, 2016 at

http://www.ville-ge.ch/musinfo/bd/cjb/africa/recherche.php), Xycol database (The list of scientific and vernacular woods names: accessed October 26, 2016 from http://www.xycol.net/index.php?categorie=0\&sess_langue=430), The Global plants database (Accessed January 10, 2017 from http://plants.jstor.org), and The working list of all plant species database (Retrieved February 16, 2017 from http://www.theplantlist.org). CN is commercial name; PT is phytogeographical type of each species recorded in study area follows the Conservatory and botanical garden of Geneva, Switzerland and South African national biodiversity institute, Pretoria (accessed on November 12, 2016 at http://www.ville-ge.ch/musinfo/bd/cjb/africa/recherche.php), and Xycol database (The list of scientific and vernacular woods names: Accessed November 12, 2016 from http://www.xycol.net/index.php?categorie $=0 \&$ sess_langue $=430$ ); TA: Tropical Africa Area (EPFAT Area, country-based, south of Sahara, complementary to the following), SA: Southern Africa Area (South Africa, Namibia, Botswana, Lesotho, and Swaziland), NA: North Africa (Mauritania, Morocco, Canary IsI., Algeria, Tunisia, Libya, Egypt, and Madeira), MA: Madagascar (Malagasy Republic), ML: Malaysia (Tropical Asia), UN: Undetermined, WA: West Africa area, SE: South-East Asia area, LA: Latin America area; $n$ is number of individuals (tree) for each species recorded in each study site of Ipendja forest; DBH is the mean of diameter at breast height $(\mathrm{in} \mathrm{cm})$ for each species in studied sites; Height is the average trees height (in $\mathrm{m}$ ) of species in each study site; WSG is mean of wood specific gravity (in $\mathrm{g} \cdot \mathrm{cm}^{-3}$ ) values retrieved from the global wood density database at http://datadryad.org/handle/10255/dryad.235 (Accessed January 13, 2016) ([39] [40]); P is plot which tree species has been founded in each study site; AGB is aboveground biomass $\left(\mathrm{Mg}^{-h^{-1}}\right)$ for each species in study site, and BGB is belowground biomass $\left(\mathrm{Mg}^{-h a^{-1}}\right)$ for each species in study site.

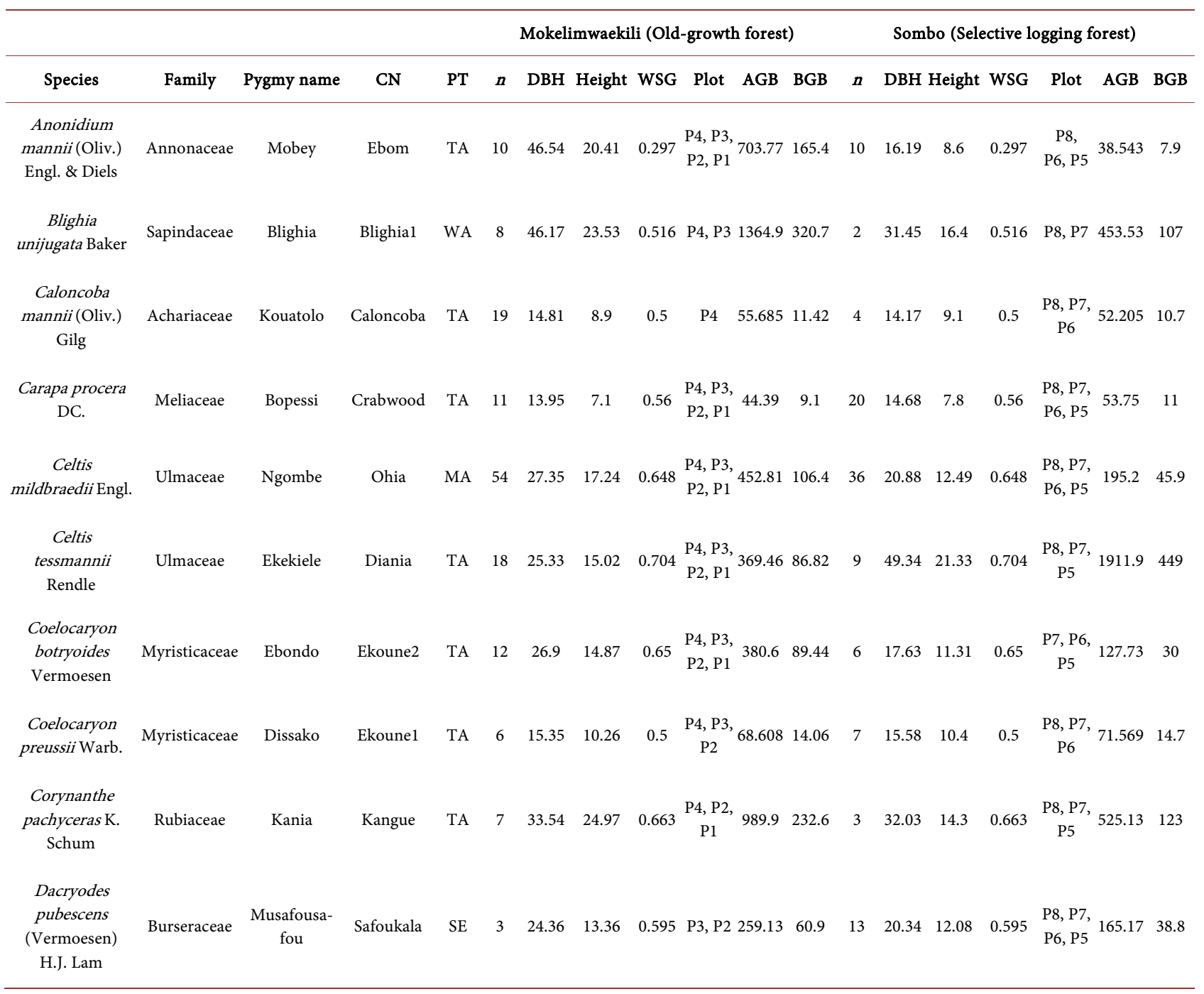




\section{Continued}

\begin{tabular}{|c|c|c|c|c|c|c|c|c|c|c|c|c|c|c|c|c|c|c|}
\hline $\begin{array}{c}\text { Dialium } \\
\text { dinklagei Harms }\end{array}$ & Caesalpiniaceae & Mbasso & Eyoum3 & TA & 4 & 29.5 & 14.17 & 0.772 & $\begin{array}{l}\mathrm{P} 3, \mathrm{P} 2, \\
\mathrm{P} 1\end{array}$ & 514.23 & 120.8 & 8 & 22.88 & 14.83 & 0.772 & $\begin{array}{l}\text { P8, P7, } \\
\text { P6 }\end{array}$ & 327.36 & 76.9 \\
\hline $\begin{array}{c}\text { Diospyros } \\
\text { perrieri (Hiern) } \\
\text { Jumelle }\end{array}$ & Ebenaceae & $\begin{array}{l}\text { Nzete ya } \\
\text { mino }\end{array}$ & Ebene 5 & SE & 6 & 17.3 & 7.9 & 0.5 & P4, P3 & 67.137 & 13.76 & 9 & 13.24 & 7.7 & 0.5 & $\begin{array}{l}\text { P7, P6, } \\
\text { P5 }\end{array}$ & 38.846 & 7.96 \\
\hline $\begin{array}{c}\text { Duboscia } \\
\text { macrocarpa Bocp. }\end{array}$ & Tiliaceae & Ekaka & Akak & ML & 11 & 31.08 & 17.74 & 0.5 & $\begin{array}{l}\text { P4, P3, } \\
\text { P2 }\end{array}$ & 463.99 & 109 & 12 & 29.62 & 16.3 & 0.5 & $\begin{array}{l}\text { P8, P7, } \\
\text { P6, P5 }\end{array}$ & 388.9 & 91.4 \\
\hline $\begin{array}{c}\text { Entandrophragma } \\
\text { angolense } \\
\text { (Welw.ex C. DC.) } \\
\text { C. DC. }\end{array}$ & Meliaceae & Diboyo & Sapeli & TA & 6 & 61.5 & 29.16 & 0.508 & $\begin{array}{l}\text { P4, P3, } \\
\text { P1 }\end{array}$ & 2900.4 & 681.6 & 8 & 48.07 & 17.78 & 0.508 & P7, P5 & 1106.3 & 260 \\
\hline $\begin{array}{c}\text { Entandrophragma } \\
\text { candollei Harms }\end{array}$ & Meliaceae & Etembekesso & Kosipo & TA & 2 & 25.75 & 24.05 & 0.603 & P3, P1 & 519.29 & 122 & 7 & 17.27 & 10.75 & 0.603 & $\begin{array}{l}\text { P8, P7, } \\
\text { P6, P5 }\end{array}$ & 108.51 & 22.2 \\
\hline $\begin{array}{c}\text { Eribroma oblonga } \\
\text { (Mast.) Pierre ex } \\
\text { A. Chev. }\end{array}$ & Sterculiaceae & Gboyo & Eyong & LA & 2 & 75.75 & 38.3 & 0.69 & P3, P1 & 7664.6 & 1801 & 9 & 26.27 & 15.93 & 0.69 & P6, P5 & 411.98 & 96.8 \\
\hline $\begin{array}{c}\text { Funtumia africana } \\
\text { (Benth.) Stapf }\end{array}$ & Apocynaceae & Ndembo & Dembo & TA & 6 & 24.7 & 17 & 0.416 & $\begin{array}{l}\mathrm{P} 4, \mathrm{P} 2, \\
\mathrm{P} 1\end{array}$ & 237.53 & 55.82 & 8 & 23.17 & 11.83 & 0.416 & $\begin{array}{l}\text { P8, P7, } \\
\text { P6 }\end{array}$ & 147.17 & 34.6 \\
\hline $\begin{array}{c}\text { Gambeya africana } \\
\text { (A. DC.) Pierre }\end{array}$ & Sapotaceae & Bobambu & $\begin{array}{l}\text { Longhi } \\
\text { rouge }\end{array}$ & TA & 12 & 33.5 & 18.17 & 0.669 & $\begin{array}{l}\text { P4, P3, } \\
\text { P2, P1 }\end{array}$ & 730.55 & 171.7 & 22 & 26.44 & 15.59 & 0.669 & $\begin{array}{l}\text { P8, P7, } \\
\text { P6, P5 }\end{array}$ & 396.37 & 93.1 \\
\hline $\begin{array}{c}\text { Gambeya beguei } \\
\text { (Aubrev. \& } \\
\text { Pellegr.) }\end{array}$ & Sapotaceae & Monopi & $\begin{array}{l}\text { Longhi } \\
\text { blanc }\end{array}$ & TA & 2 & 15.6 & 7.6 & 0.5 & P3, P1 & 52.828 & 10.83 & 24 & 23.47 & 12.22 & 0.5 & $\begin{array}{l}\text { P7, P6, } \\
\text { P5 }\end{array}$ & 186.39 & 43.8 \\
\hline $\begin{array}{l}\text { Ganophyllum } \\
\text { giganteum } \\
\text { (A.Cheval.) } \\
\text { Haumann }\end{array}$ & Sapindaceae & Ekomou & Mokenjo & SE & 12 & 13.82 & 8.2 & 0.698 & $\begin{array}{l}\mathrm{P} 4, \mathrm{P} 2, \\
\mathrm{P} 1\end{array}$ & 62.197 & 12.75 & 2 & 19 & 10.55 & 0.698 & P6, P5 & 148.06 & 34.8 \\
\hline $\begin{array}{c}\text { Garcinia } \\
\text { atroviridis Griff. } \\
\text { ex T. Anderson }\end{array}$ & Clusiaceae & Mokata & Garcinia & ML & 3 & 16 & 10.66 & 0.5 & P4 & 77.222 & 15.83 & 33 & 17.32 & 10.15 & 0.5 & $\begin{array}{l}\text { P8, P7, } \\
\text { P6, P5 }\end{array}$ & 85.934 & 17.6 \\
\hline $\begin{array}{c}\text { Guarea } \\
\text { thompsonii } \\
\text { Sprague \& Hutch. }\end{array}$ & Meliaceae & Mbenia & Bosse fonce & TA & 20 & 18.2 & 9.3 & 0.56 & $\begin{array}{l}\text { P4, P3, } \\
\text { P2, P1 }\end{array}$ & 97.083 & 19.9 & 15 & 20.92 & 10.73 & 0.56 & $\begin{array}{l}\text { P8, P6, } \\
\text { P5 }\end{array}$ & 146.5 & 34.4 \\
\hline $\begin{array}{l}\text { Khaya anthotheca } \\
\text { (Welw.) C. DC. }\end{array}$ & Meliaceae & Deke & Acajou & SA & 7 & 32.3 & 15.04 & 0.53 & $\begin{array}{l}\text { P4, P3, } \\
\text { P2, P1 }\end{array}$ & 450.68 & 105.9 & 7 & 17.68 & 9.5 & 0.53 & $\begin{array}{l}\text { P8, P7, } \\
\text { P6, P5 }\end{array}$ & 88.767 & 18.2 \\
\hline $\begin{array}{c}\text { Lannea } \\
\text { welwitschii } \\
\text { (Hiern) Engl. }\end{array}$ & Anacardiaceae & Gondo & Kumbi & TA & 5 & 26.65 & 13.58 & 0.469 & $\mathrm{P} 2, \mathrm{P} 1$ & 248.74 & 58.45 & 15 & 21.76 & 12.89 & 0.469 & $\begin{array}{l}\text { P8, P7, } \\
\text { P6, P5 }\end{array}$ & 159.15 & 37.4 \\
\hline $\begin{array}{c}\text { Macaranga } \\
\text { barteri Mull. Arg. }\end{array}$ & Euphorbiaceae & Mossomba1 & Mossombal & TA & 1 & 23.6 & 8.2 & 0.5 & P4 & 127.65 & 30 & 20 & 22.31 & 13 & 0.5 & $\begin{array}{l}\text { P8, P7, } \\
\text { P6, P5 }\end{array}$ & 179.35 & 42.1 \\
\hline $\begin{array}{c}\text { Nesogordonia } \\
\text { kabingaensis } \\
\text { (K.Schum.) } \\
\text { Capuron ex R. } \\
\text { Germ. }\end{array}$ & Sterculiaceae & Moduka & Kotibe & TA & 14 & 29.01 & 20.77 & 0.681 & $\begin{array}{l}\text { P4, P3, } \\
\text { P2, P1 }\end{array}$ & 639.55 & 150.3 & 5 & 24 & 14.62 & 0.681 & P7, P6 & 313.57 & 73.7 \\
\hline $\begin{array}{c}\text { Panda oleosa } \\
\text { Pierre }\end{array}$ & Pandaceae & Mokana & Afan & TA & 3 & 22.46 & 17 & 0.565 & P3, P2 & 266 & 62.51 & 10 & 35.18 & 16.71 & 0.565 & P8 & 628.07 & 148 \\
\hline $\begin{array}{c}\text { Petersianthus } \\
\text { macrocarpus } \\
\text { (P.Beauv.) Liben }\end{array}$ & Lecythidaceae & Bosso & Essia & WA & 20 & 32.05 & 19.3 & 0.769 & $\begin{array}{l}\text { P4, P3, } \\
\text { P2, P1 }\end{array}$ & 814.25 & 191.3 & 15 & 33.04 & 15.72 & 0.769 & $\begin{array}{c}\text { P8, P6, } \\
\text { P5 }\end{array}$ & 707.27 & 166 \\
\hline
\end{tabular}




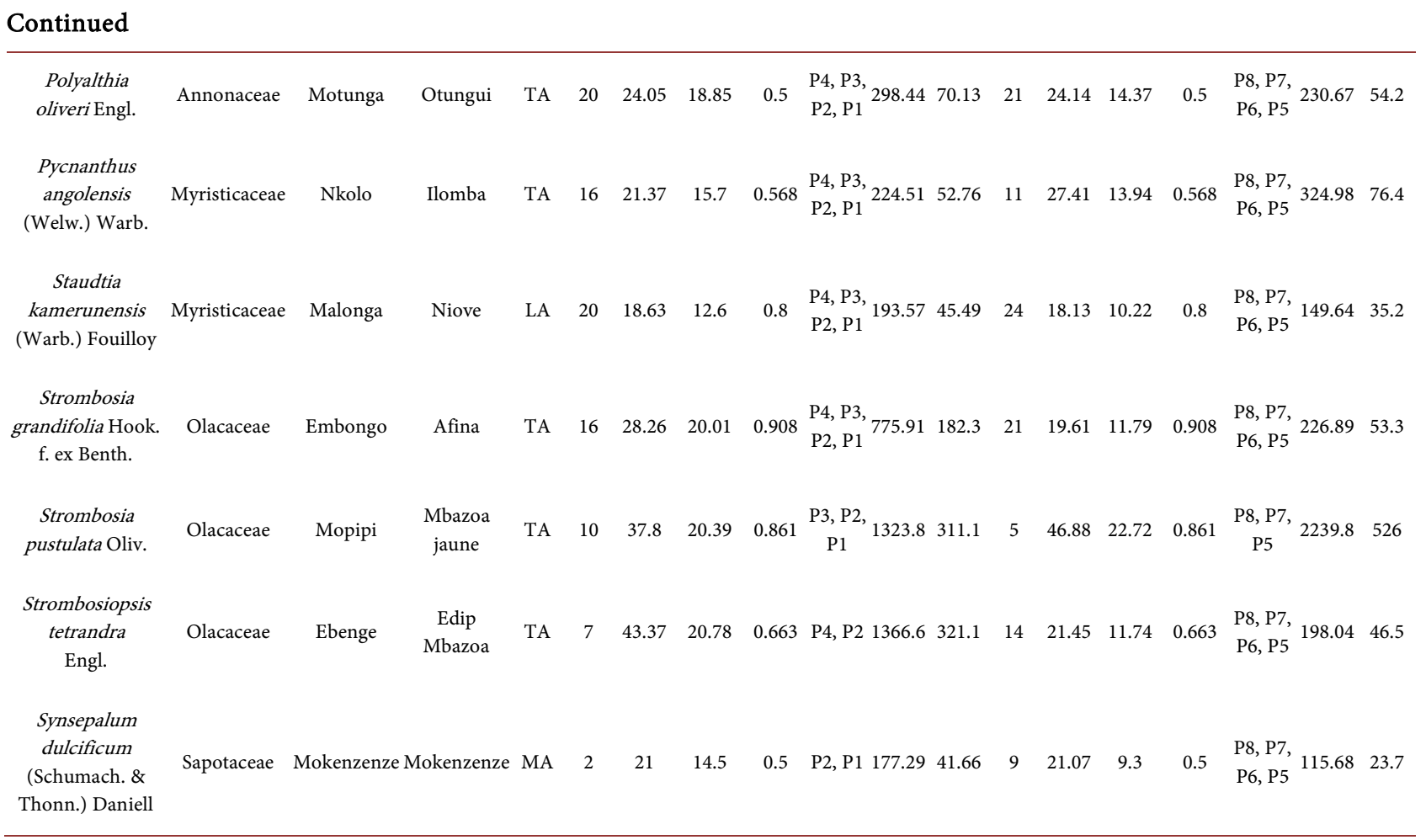

\subsubsection{Diameter-Height Allometry}

The choice of a model is a crucial step because the largest source of error in estimating biomass is associated with it [6]. Site-specific models are preferred to international standard model [18] because allometric relationships differ from one region to another depending on environmental factors (such as soil and climate) and functional traits of species (such as wood density and crown architecture) (Figure 3). However, there are no allometric equations available for Ipendja evergreen lowland forest. Thus, based on the climatic conditions of the study sites (Mokelimwaekili and Sombo) and [18] findings, aboveground biomass (AGB) was calculated following [18], using the formula for all pantropical forests and taking tree height into account (1) and (2). The model including tree height was chosen since [8] [28] [30] [32] [34] pointed out that neglecting tree height in the estimation of biomass leads to significant errors. This model was developed from various tropical forests based on the compilation of data from 58 study sites in Africa, America, Asia and Oceania. The samples were collected from 4004 trees, including 1006 trees from tropical Africa.

\subsubsection{Harvest Dataset Compilation}

In this research, we compiled tree harvest studies that had been carried out in old-growth and selective logging forests, respectively in Mokelimwaekili and Sombo (excluding plantations and agroforestry systems). The rational for this choice is that the natural variability in plant allometry tends to be minimized in plantations. The fieldwork was conducted with help from by experienced botanists, ecologists and foresters who working in Thanry-Congo logging company. 


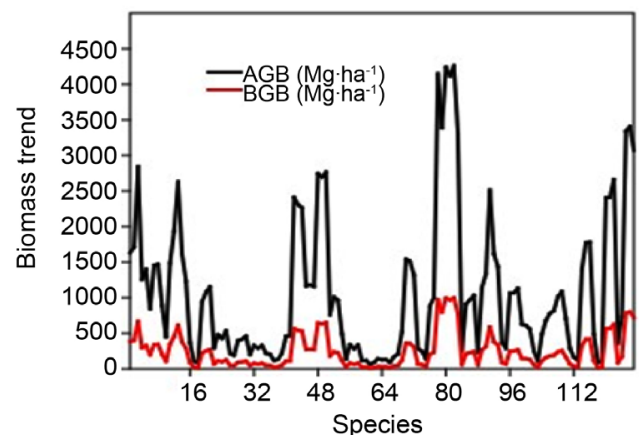

(a)

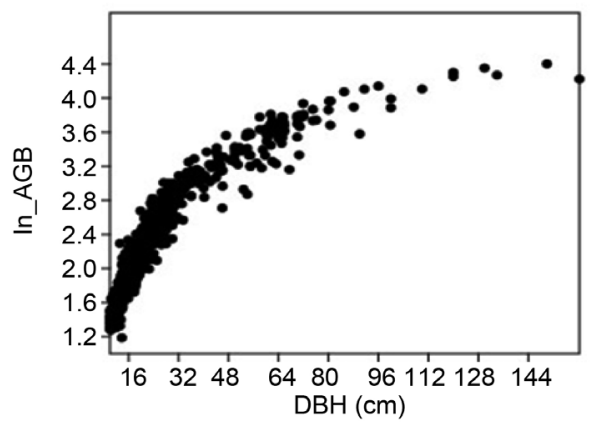

(c)

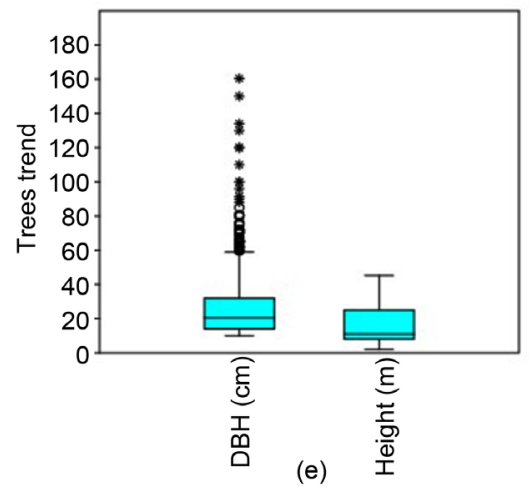

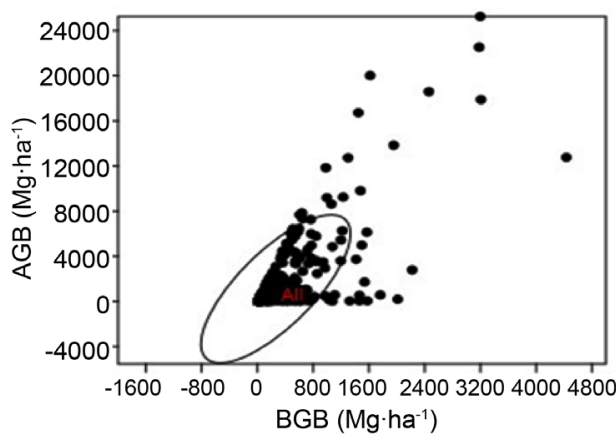

(b)

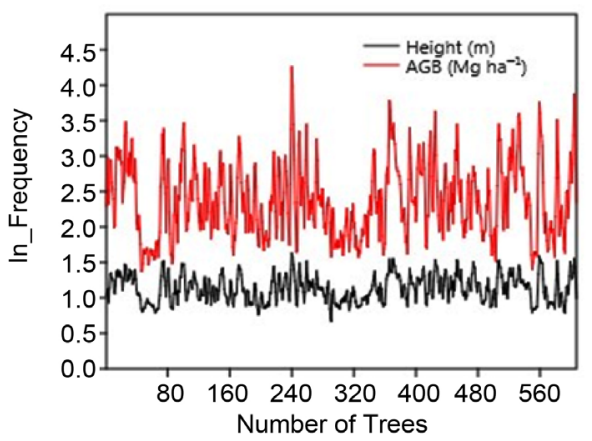

(d)

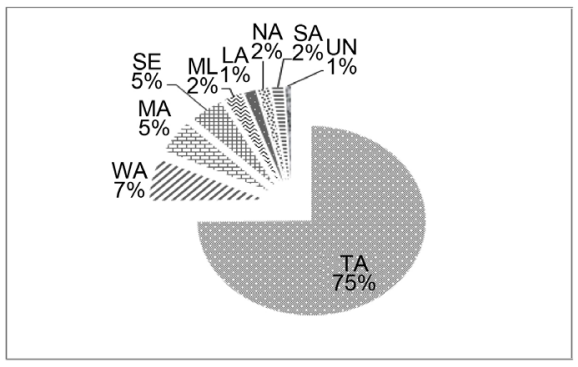

(f)

Figure 3. Relationship between aboveground biomass (AGB, in $\mathrm{Mg} \cdot \mathrm{ha}^{-1}$ ) and belowground biomass (BGB, in Mg.ha ${ }^{-1}$ ) for Mokelimwaekili (a) using the reference model proposed by [18]. Panel (b): Fitted relationship between aboveground biomass (AGB) and belowground biomass (BGB) with point style graph, 3-point average, 95\% ellipses (circle) showing similarity rate regarding total AGB and total BGB of recorded trees, frame and they are no thick lines. The expression "All" in red color (b) is highlightly showing trees group label according to them biomass trend. Panel (c): Relationship between aboveground biomass (AGB, in $\left.\mathrm{Mg} \mathrm{ha}^{-1}\right)$ and trunk diameter at breast height ( $\mathrm{DBH}$, in $\mathrm{cm}$ ). Logarithm was applied to AGB for showing highlightly trend between biomass among estimated and trunk diameter in Mokelimwaekili (c). Panel (d): Distribution of aboveground biomass (AGB, in

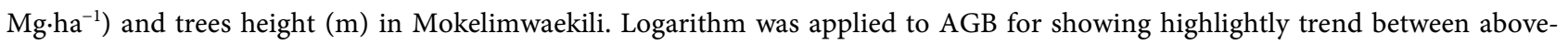
ground biomass among estimated and trees height in Mokelimwaekili (d). Three-point average has been applied on both of parameters. Panel (e): Average Diameter-height distribution of trees in Mokelimwaekili. D:H relationship (e) was performed with box plot, including outliers (quartile method: rounding). Panel (f): Phytogeographical type distribution of species regarding Mokelimwaekili. Phytogeographical type (f) has been retrieved from the conservatory and botanical garden of Geneva, Switzerland and South African national biodiversity institute, Pretoria (Accessed on November 12, 2016 at

http://www.ville-ge.ch/musinfo/bd/cjb/africa/recherche.php), and Xycol database: (Accessed November 12, 2016 from http://www.xycol.net/index.php?categorie=0\&sess_langue=430); TA: Tropical Africa Area (EPFAT Area, country-based, south of Sahara, complementary to the following), SA: Southern Africa Area (South Africa, Namibia, Botswana, Lesotho, and Swaziland), NA: North Africa (Mauritania, Morocco, Canary IsI., Algeria, Tunisia, Libya, Egypt, and Madeira), MA: Madagascar (Malagasy Republic), ML: Malaysia (Tropical Asia), UN: Undetermined, WA: West Africa area, SE: South-East Asia area, LA: Latin America area. 
To be included in the compilation, the following measurements had to be available for each tree: trunk diameter $D$ (in $\mathrm{cm}$ ), total tree height $H$ (in $\mathrm{m}$ ), wood specific gravity $\rho\left(\mathrm{g} \cdot \mathrm{cm}^{-3}\right)$ and total oven-dry AGB $\left(\mathrm{Mg} \cdot \mathrm{ha}^{-1}\right)$. We excluded trees with $\mathrm{DBH}<10 \mathrm{~cm}$ because such trees hold a small fraction of aboveground biomass (AGB) in forests and woodlands [18], and would otherwise dominate the signal in regression models (2). The common practice for measuring diameter at breast height is to measure trunk diameter at $1.3 \mathrm{~m}$ aboveground (diameter at breast height $\mathrm{DBH}$ ). Buttressed or irregular-shaped trees are measured above buttresses or trunk deformities.

For comparison, we tried to used [8]'s model on our data. So, based on the moist forest biomass model form proposed by [28], [8] developed biomass model (5), as described below, to estimate aboveground biomass $(B)$ based on just the measured diameter $(D$, in $\mathrm{cm})$ and estimated wood density $\left(\rho\right.$, in $\left.\mathrm{g} \cdot \mathrm{cm}^{-3}\right)$ using the model form (i.e., excluding tree height):

$$
B=\exp \left(a+b \times \ln (D)+c(\ln (D))^{2}-d(\ln (D))^{3}+e \times \ln (\rho)\right)
$$

Alternatively, using the $H: D$ database developed by [41], he inferred $H$ using a range of $H: D$ allometric models, and then used that inferred value in bootstrapped biomass model (6) based on the form proposed by [28] as described below. The model parameterization, which includes height $(\mathrm{H}, \mathrm{in} \mathrm{m})$ in addition to diameter and wood density $\left(\rho\right.$, in $\left.\mathrm{g} \cdot \mathrm{cm}^{-3}\right)$ is:

$$
B=\exp \left(a+b \times \ln \left(\rho D^{2} H\right)\right)
$$

According to [8], aboveground biomass (AGB) for this case has been calculated using the [28] moist biomass equation, wood density $\left(\mathrm{g} \cdot \mathrm{cm}^{-3}\right)$ and height

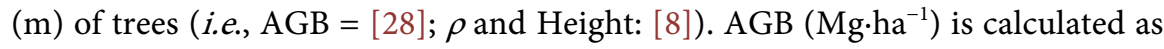
a function of tree diameter and wood specific gravity (Wood density, $\mathrm{g} \cdot \mathrm{cm}^{-3}$ ) and estimated height (in $\mathrm{m}$ ). Height has been calculated using the [41] Weibull ([18], three-parameter) model at region level. Region classification based on [41].

The model presented by [28] with two parameters such as wood density $(\rho)$ and diameter at breast height $(\mathrm{DBH})$ for moist forests has been expressed by:

$\mathrm{AGB}_{\text {est }}=\rho \times \exp \left(-1.499+2.148 \times \ln (D)+0.207 \times(\ln (D))^{2}-0.0281(\ln (D))^{3}\right)(7)$

where AGB is aboveground biomass (in $\mathrm{kg}$ ), est is an estimation, $D$ is a diameter at breast height (in $\mathrm{cm}$ ), ln is the natural logarithm, and $\rho$ is the wood density (in g. $\mathrm{cm}^{-3}$ ). [28] developed another model including the predictor height (i.e., diameter at beast height, height of tree and wood density) for moist forests. So, the model is as follows:

$$
\mathrm{AGB}_{\text {est }}=\exp \left(-2.977+\ln \left(\rho D^{2} H\right)\right) \equiv 0.0509 \times \rho D^{2} H
$$

where $\mathrm{AGB}$ is aboveground biomass (in $\mathrm{kg}$ ), est is an estimation, $D$ is a diameter 
at breast height (in $\mathrm{cm}$ ), $H$ is the height of tree (in $\mathrm{m}$ ), and $\rho$ is the wood density (in $\mathrm{g} \cdot \mathrm{cm}^{-3}$ ). Wood density is just wood specific gravity. These models already include the correction factor (7) and (8). The symbol $\equiv(8)$ means a mathematical identity (i.e., equiv.): both formulas (7) and (8) can be used in the biomass estimation procedure. The standard error in estimating aboveground biomass (AGB) is around $12 \%$ if height predictor is available and around $19 \%$ if height predictor is not available [28].

To develop the H:D allometric relationships for inclusion in biomass models, height measurements has been used for individual trees made in eight plots in two study sites representing 1340 trees concurrent height $(H)$ and trunk diameter $(D)$ measurements. Nondestructive data has been used during our study. Only permanent plots trees have been used for processing.

Nevertheless, stand basal area $(G)$ for each census was calculated as:

$$
G=\frac{\left(\sum n \times \pi \times\left(\frac{D_{i}}{2}\right)^{2}\right)}{h a}
$$

where $G$ is basal area (in $\mathrm{m}^{2} \cdot \mathrm{ha}^{-1}$ ), $D_{i}$ is diameter at breast height of individual $i$ at $1.3 \mathrm{~m}$ above the ground $(\mathrm{cm}), \pi$ is 3.14 and $n$ is the number of stems per plot. Basal area is the area of a given section of land that is occupied by the cross-section of tree trunk and stem (9) at the base [37] [41]. Measurement taken at the DBH of tree above the ground (9) and include the complete of every tree, including the bark [33].

However, the PAST program used includes standard statistical tests [42]. The data of this study were compiled with SigmaPlot v.10.0 and PAST v.3.05 statistical softwares. Study area's location map has been performed using the ArcGIS v.9.3 software.

\section{Results}

\subsection{Plant Communities' Assessment}

1340 trees were identified after analysis from the floristic inventory performed (Table 1). These trees are grouped into 36 botanical families and 145 species in Ipendja forest. The most represented families with at least 6 percent were: Sapotaceae (10\%), Euphorbiaceae (8\%), Meliaceae (8\%) and Sterculiaceae (6\%) (Table 2). Celtis mildbraedii Engl. (62\%), followed by Staudtia kamerunensis (Warb.) Fouilloy (30\%), Polyalthia olivera Engl. (28\%), Strombosia grandifolia Hook. f. ex Benth. (25\%), and Garcinia atroviridis Griff. Ex T. Anderson (24\%) were the leading species regarding relative frequency in the study area. In 145 species of Ipendja mixed evergreen lowland forest, we recorded 90 common species. A total of 1340 trees were distributed into two studied sites, respectively Mokelimwaekili (site1, $n=607$ ) and Sombo (site2, $n=733$ ). Trees from Mokelimwaekili site $(n=607)$ are grouped into 34 families and 127 species. Trees from Sombo site $(n=733)$ are grouped into 33 botanical families and 109 species. 


\subsection{Phytogeographical Type Distribution}

The Tropical Africa Area (EPFAT Area, country-based, south of Sahara, complementary to the following) species was the most recorded representative on phytogeographical level and corresponded with $75 \%$ and $72 \%$ of identified species respectively for Mokelimwaekili and Sombo sites (Table 2 and Figure 4). On chorological level, the tropical Africa area (EPFAT Area, country-based, south of Sahara, complementary to the following) (72\%) followed by West Africa area (5\%), Madagascar (Malagasy Republic) (5\%), South-East Asia area (5\%) and Latin America area (5\%) were the most important phytogeographical types for Sombo (Figure 4(f)). However, the tropical Africa area (EPFAT Area, country-based, south of Sahara, complementary to the following) (75\%) followed by West Africa area (7\%), Madagascar (Malagasy Republic) (5\%) and South-East Asia area (5\%) were the most important phytogeographical types for Mokelimwaekili (Figure 3(f)). Latin America area species had higher proportion of phytogeographical type in the Sombo forest (5\%) than Mokelimwaekili forest (1\%). However, most phytogeographical types were founded from African plant database (see http://www.ville-ge.ch/cjb/). Phytogeographical type is to organize and to give us understanding about origin of species. Some species are from others regions and can be adapted in them actual location. African plant database is a platform who recorded the database currently comprises 200,869 names of African plants with their nomenclatural status. Data capture, edition and broadcast are the product of collaboration between the South African biodiversity institute, the Geneva conservatory and botanical garden, Tela Botanica and the Missouri botanical garden.

\subsection{Aboveground Biomass Estimation}

Mean aboveground biomass (AGB) across eight measured plots ranged from 196.9 to $656.1 \mathrm{Mg} \cdot \mathrm{ha}^{-1}$ (Table 1 and Figure 5) using reference model developed by [18]. The mean of AGB in total study area were $346 \mathrm{Mg} \cdot h a^{-1}$ with a standard error of 53.1\%. One-way ANOVA analysis at $P$-level $<0.05$ showed significant difference in means aboveground biomass for the studied forest $(F=23.46, \mathrm{df}=$ 7.771, $P=0.00139)$. Levene's test for homogeneity of variance for means shows a significant difference $(P=0.0184)$. Kruskal-Wallis test for equal median shows that there is a significant difference between Mokelimwaekili and Sombo $(P=$ 0.0007). Two-sample paired test were applied on Mokelimwaekili and Sombo and shows a significant difference for t-test (Mean difference: 215.43, confidence interval at 95\%: $0.54-430.32, P=0.049$ ), for Wilcoxin test (normal approximation inaccurate): $P=0.06$. One-way ANOVA applied on Mokelimwaekili and Sombo revealed significant difference regarding the test for equal means ( $F=$ 8.48, $\mathrm{df}=1, P=0.0269)$, for the Welch $F$-test in the case of unequal variance: $F=$ 8.481, $\mathrm{df}=3.415, P=0.0528$. Kruskal-Wallis test shows that there is significant difference between Mokelimwaekili and Sombo $(P=0.02092)$. Levene's test show a significant difference between Mokelimwaekili and Sombo $(P=0.0143)$. 


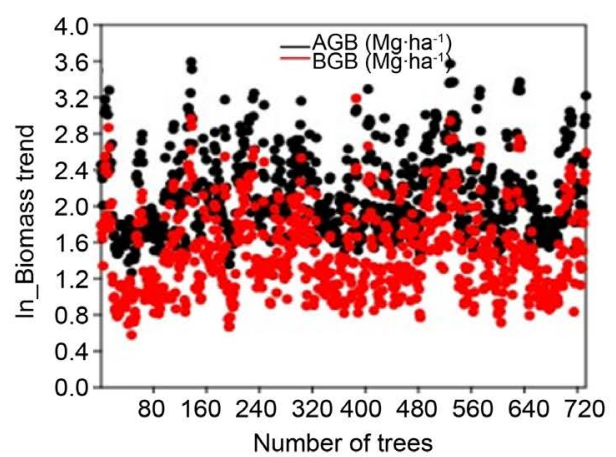

(a)

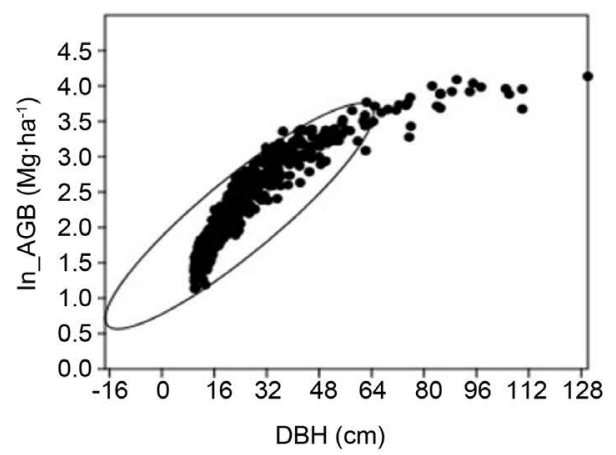

(c)

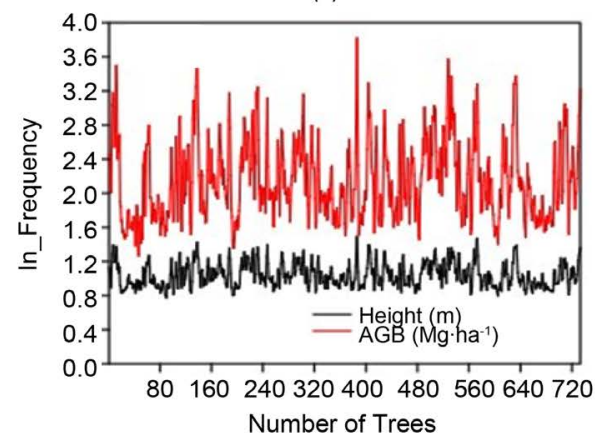

(e)

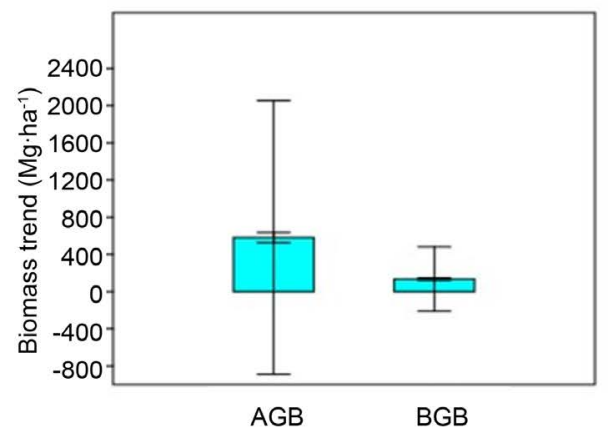

(b)

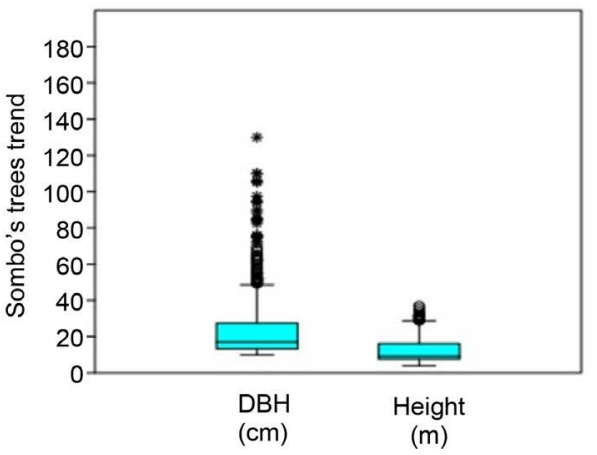

(d)

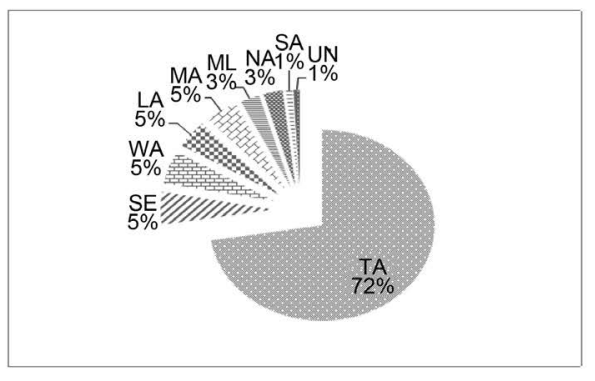

(f)

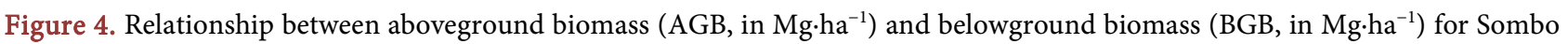
(a) using the reference model proposed by [18] (1) with the point style graph, 3-point average, thick lines, frames and logarithm of AGB and BGB. Panel (b): Fitted relationship between aboveground biomass (AGB) and belowground biomass (BGB) for Sombo site with bar chart graph, whisker type: standard error and standard deviation, whisker length: 95\% interval, frame and they are not thick lines. Panel (c): Relationship between aboveground biomass (AGB, in $\mathrm{Mg} \cdot \mathrm{ha}^{-1}$ ) and trunk diameter at breast height $(\mathrm{DBH}$, in $\mathrm{cm})$. Logarithm was applied to AGB for showing highlightly trend between biomass among estimated and trunk diameter in Sombo (c). Panel (d): Average Diameter-height distribution of trees in Sombo. D:H relationship (d) was performed with box plot, including outliers (quartile method: rounding). Panel (e): Distribution of aboveground biomass (AGB, in Mg.ha ${ }^{-1}$ ) and total tree height $(\mathrm{m})$ in Sombo. Logarithm was applied to AGB for showing highlightly trend between aboveground biomass among estimated and trees height in Sombo (e). Three-point average has been applied (e) on both of parameters. Panel (f): Phytogeographical type distribution of species about Sombo. Phytogeographical type (f) of Sombo has been retrieved from the conservatory and botanical garden of Geneva, Switzerland and South African national biodiversity institute, Pretoria (accessed on November 12, 2016 at http://www.ville-ge.ch/musinfo/bd/cjb/africa/recherche.php), and Xycol database: (Accessed November 12, 2016 from http://www.xycol.net/index.php?categorie=0\&sess_langue=430); TA: Tropical Africa Area (EPFAT Area, country-based, south of Sahara, complementary to the following), SA: Southern Africa Area (South Africa, Namibia, Botswana, Lesotho, and Swaziland), NA: North Africa (Mauritania, Morocco, Canary IsI., Algeria, Tunisia, Libya, Egypt, and Madeira), MA: Madagascar (Malagasy Republic), ML: Malaysia (Tropical Asia), UN: Undetermined, WA: West Africa area, SE: South-East Asia area, LA: Latin America area. 
In Mokelimwaekili forest, the model developed by [18] provided good mean biomass estimates $\left(\mathrm{AGB}=559.7 \mathrm{Mg} \cdot \mathrm{ha}^{-1}\right.$ ), while the model developed by [11] for tropical forests predicted much lower mean biomass values $\left(\mathrm{AGB}=6.1 \mathrm{Mg} \cdot \mathrm{ha}^{-1}\right.$ ), and this was even much lower for the Sombo forest $\left(\mathrm{AGB}=5.4 \mathrm{Mg} \cdot \mathrm{ha}^{-1}\right.$ ) $($ Table 3 ). So by this result the model of [11] is not valid at Ipendja (Table 3). The biomass predictions of the most recent pantropical model [18], including a measure of environmental stress in the set of predictors, tended to be higher in the Mokelimwaekili forest $\left(\mathrm{AGB}=559.7 \mathrm{Mg} \cdot \mathrm{ha}^{-1}\right.$ ) but were much closer for the Sombo forest $\left(\mathrm{AGB}=291.8 \mathrm{Mg} \cdot \mathrm{ha}^{-1}\right.$ ) to the values predicted by this most recent pantropical model but including site-specific height-diameter allometry. Figure 3 shows that in Mokelimwaekili site, AGB were higher compared with BGB. Figure 4 showed the relationship between aboveground biomass ( $\mathrm{AGB}$, in $\mathrm{Mg}^{\mathrm{h}} \mathrm{ha}^{-1}$ )

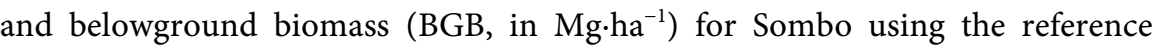
model proposed by [18]. In Sombo also, AGB recorded were higher than BGB as asserted in Figure 4. However, Figure 6 shows the relationship between AGB and BGB for eight plots of study area. AGB were important in among compared with BGB (Figure 6) in Ipendja forest. It was obvious that AGB in Mokelimwaekili were higher than those of Sombo (Figure 5(c)).

\subsection{Belowground Biomass Estimation}

Mean belowground biomass (BGB) across eight repeat measured plots ranged from 46.2 to $154.1 \mathrm{Mg} \cdot \mathrm{ha}^{-1}$ (Table 1) using the model presented by [35]. We founded a mean of BGB for total studied area of $81.3 \mathrm{Mg} \cdot \mathrm{ha}^{-1}$ with a standard error of $12.5 \%$ and the standard deviation of $35.3 \%$. One-way ANOVA for BGB applied in 8 studied plots shows that there is a significant difference between plots and sites $(F=19.34, \mathrm{df}=7.096, P=0.003)$. Test for equal means shows that there is a significant difference between sites $(F=19.34$, df $=1, P=0.0006)$. Levene's test for homogeneity of variance from means showed that there is a significant difference between plots and sites $(P=0.0058)$. Levene's test from medians showed that there is significantly different between plots and sites $(P=$ $0.0224)$. Kruskal-Wallis test for equal medians showed that there is a significant difference between studied plots about BGB ( $P=0.0007, H\left(\right.$ chi $\left.^{2}\right)$ : 11.29). One-sample test within t-test showed that there is not significantly different for BGB distribution in Ipendja forest ( $P=0.999 ; 96 \%$ confidence interval: $(-29.55$ 29.57; $t=0.0008$ ). Wilcoxon test (one-sample test) showed that there is not significantly different for belowground biomass distribution in Ipendja lowland forest ecosystem $(P=0.64)$. F-test for equal variances shows for BGB the variance of 1250.3 and a significant difference $(P=0.001)$. Mann-Whitney test for equal medians applied to BGB shows a significant difference for eight studied plots $(P=0.0001)$. Fligner-Kileen test for equal coefficients of variation for BGB showed the follows results: $\mathrm{CV}=43.48 \%$ with $95 \%$ of confidence intervals (32.497 - 67.95). Kolmogorov-Smirnov test for equal distribution shows a significant difference in eight plots for BGB $(P=0.0001)$. Figure 5 shows the 


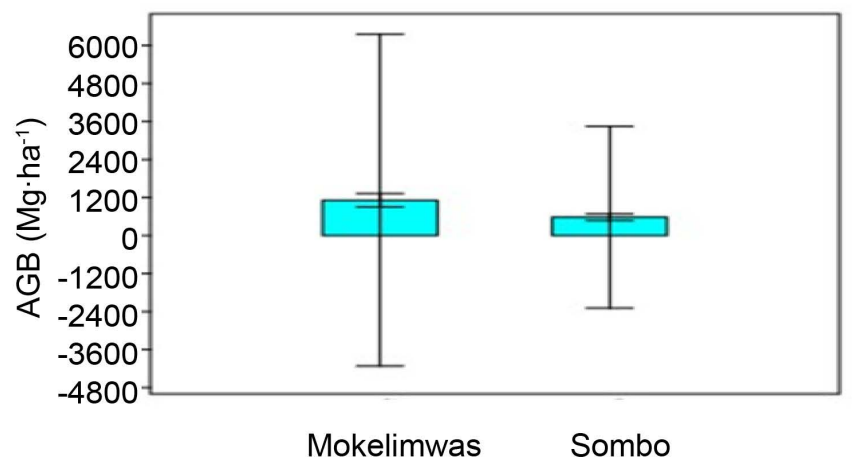

(a)

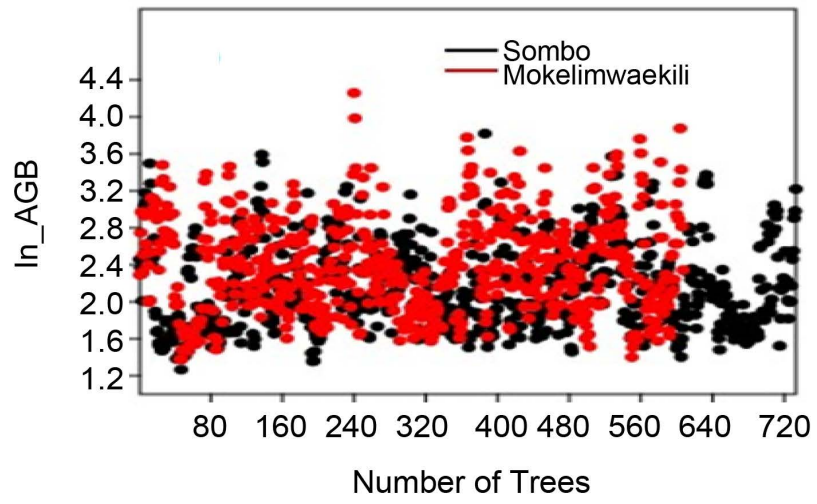

(c)

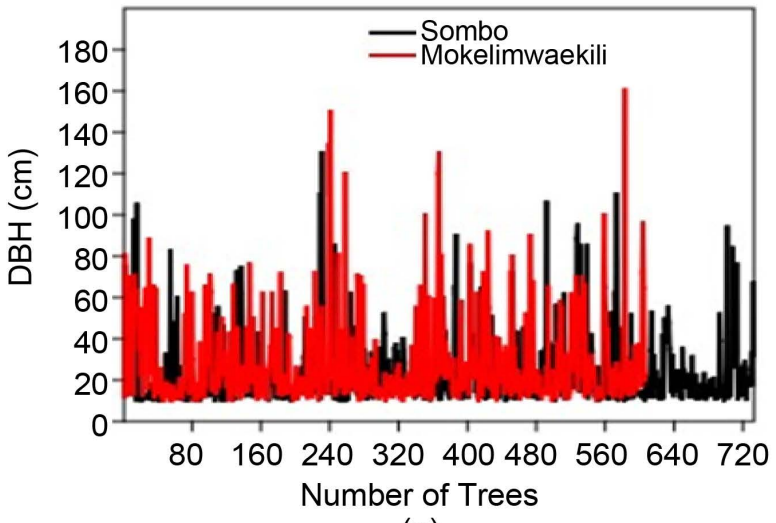

(e)

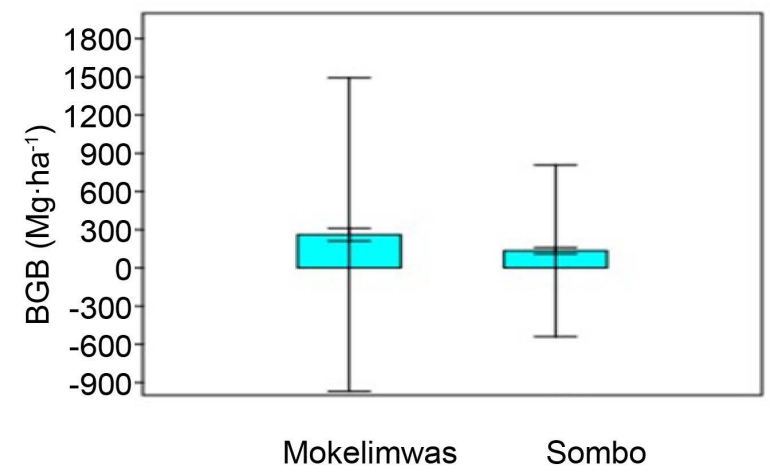

(b)

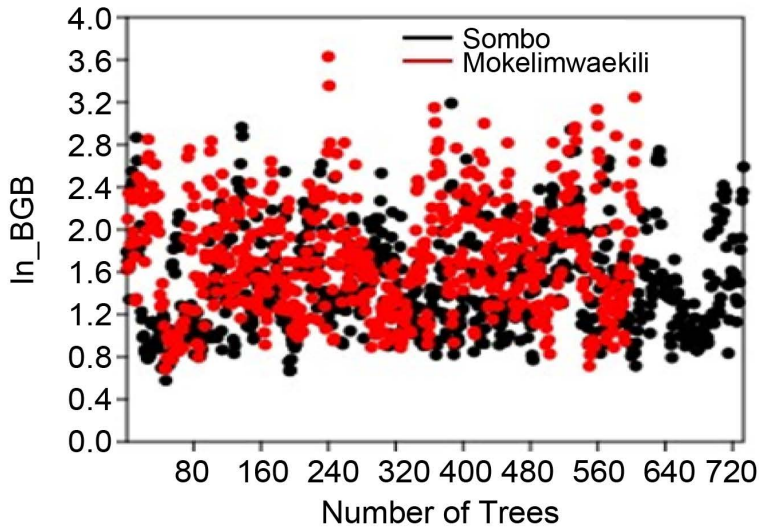

(d)

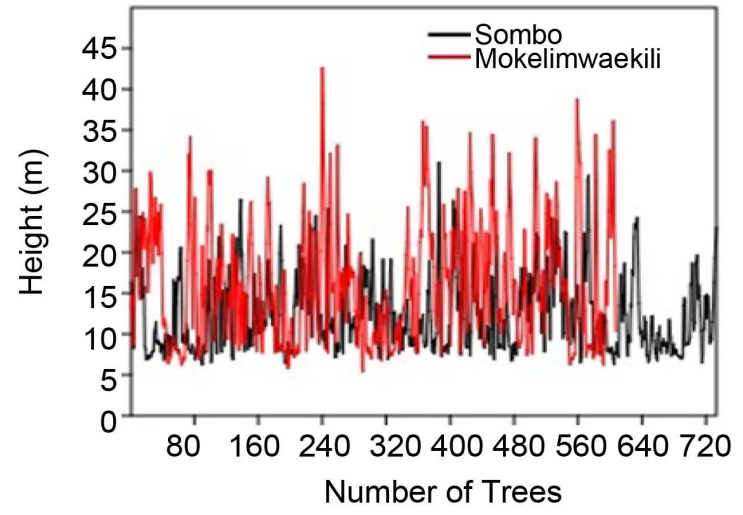

(f)

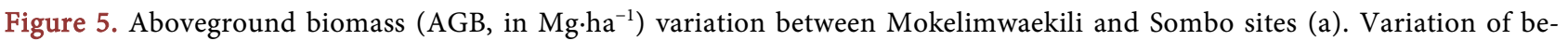

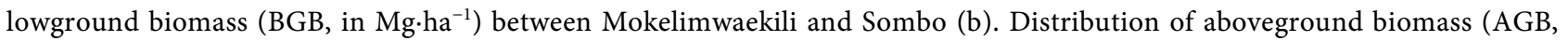
in $\mathrm{Mg} \cdot \mathrm{ha}^{-1}$ ) Mokelimwaekili and Sombo by number of trees (c). Distribution of belowground biomass (BGB, in $\mathrm{Mg} \cdot \mathrm{ha}{ }^{-1}$ ) in Mokelimwaekili and Sombo by number of trees (d). Mokelimwaekili and Sombo sites' relationship about tree trunk diameter at breast height $(\mathrm{DBH}$, in $\mathrm{cm})(\mathrm{e})$. Mokelimwaekili and Sombo sites' relationship regarding total tree height (Height, in $\mathrm{m})$ (f).

distribution of belowground biomass in Mokelimwaekili and Sombo respectively site 1 and site 2 by number of trees. It was obvious that BGB in Mokelimwaekili were higher than those of Sombo (Figure 5(d)).

\subsection{Carbon Stocks Distribution}

Carbon stock was estimated from the total biomass (above- and below-ground 


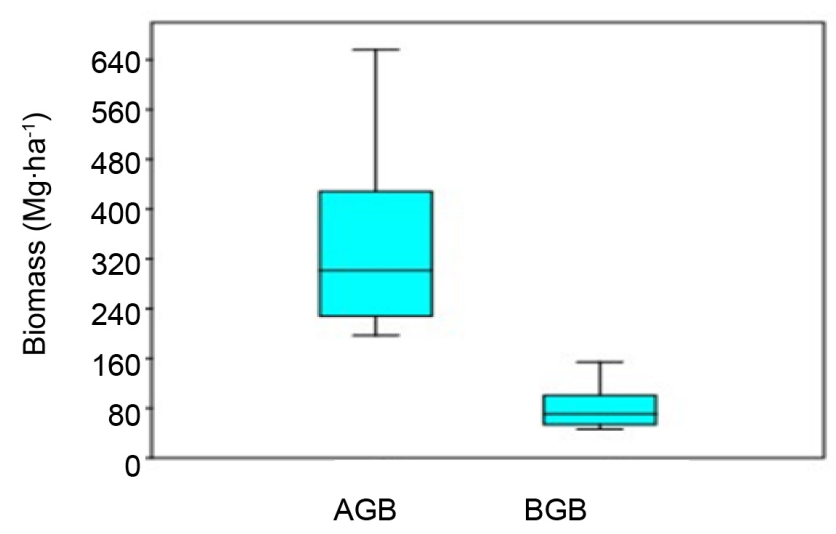

(a)

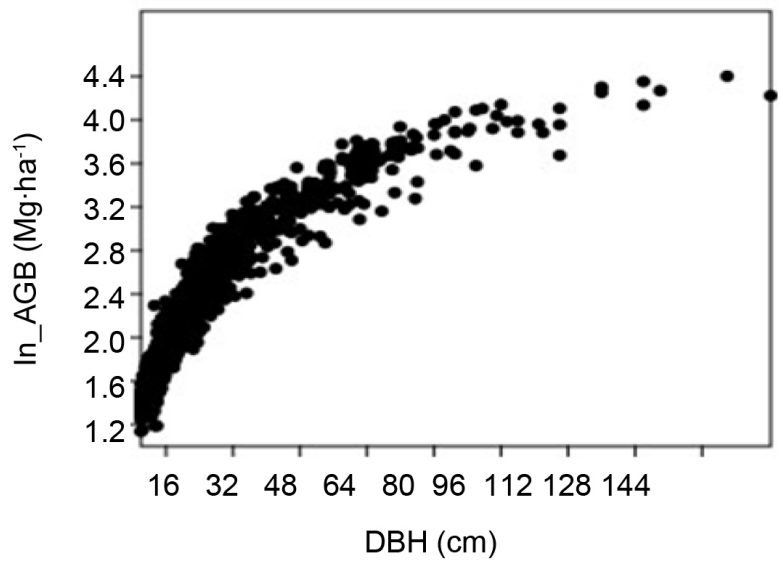

(c)

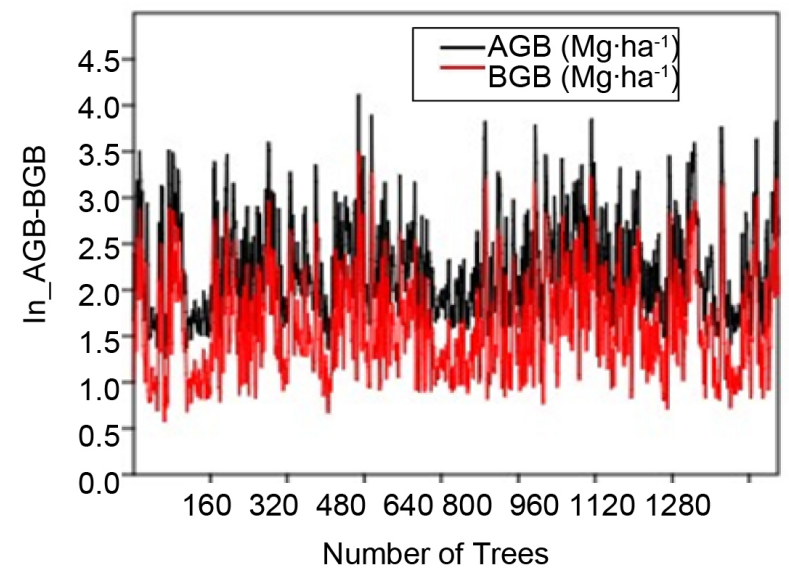

(b)

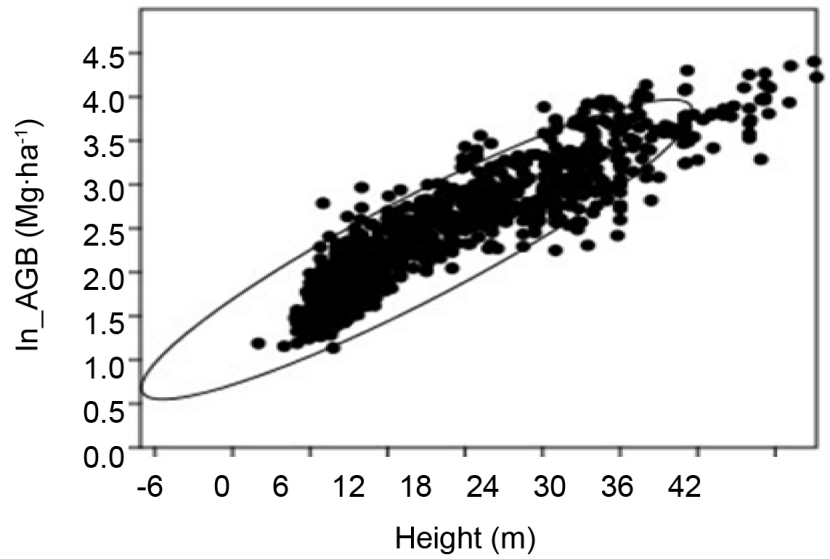

(d)

Figure 6. Panel (a): Relationship between aboveground biomass (AGB, in $\mathrm{Mg}^{-h^{-1}}{ }^{\text {) }}$ and belowground biomass (BGB, in Mg.ha ${ }^{-1}$ ) for eight plots of study area with bar chart graph, whisker type: standard error and standard deviation, whisker length: $95 \%$ interval, frame and they are not thick lines. Panel (b): Total aboveground biomass (AGB, in $\mathrm{Mg} \cdot \mathrm{ha}^{-1}$ ) and belowground biomass (BGB, in $\mathrm{Mg} \cdot \mathrm{ha}^{-1}$ ) with three-point average and logarithm of above- and below-ground biomass by total number of trees recorded in

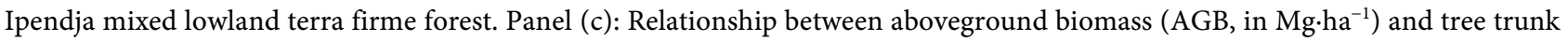
diameter at breast height $(\mathrm{DBH}$, in $\mathrm{cm})$. Logarithm was applied to aboveground biomass (AGB) for showing highlightly trend between biomass among estimated and trees trunk diameter at breast height in total 8 plots of study area. Panel (d): Distribution of aboveground biomass ( $\mathrm{AGB}$, in $\mathrm{Mg} \cdot \mathrm{ha}^{-1}$ ) and trees height $(\mathrm{m})$ in Ipendja forest. Logarithm was applied to aboveground biomass (AGB) for showing highlightly trend between aboveground biomass among estimated and trees height in 8 plots of study area.

biomass) of tree and was estimated to be about $50 \%$ of total tree biomass [2] [24] [26]. To estimate carbon stock, the biomass (above- and below-ground biomass) was devised by two to obtain the carbon stock for each plot [2] [3] [24]. For example, aboveground biomass (AGB) of plot1 recorded in Mokelimwaekili forest ecosystem was $656.1 \mathrm{Mg} \cdot \mathrm{ha}^{-1}$ and belowground biomass (BGB) was 154.1

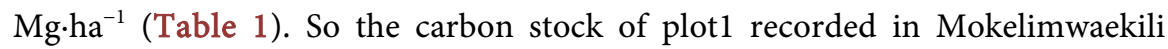
forest was $328 \mathrm{Mg} \cdot \mathrm{ha}^{-1}$ and $77 \mathrm{Mg} \cdot \mathrm{ha}^{-1}$ respectively for aboveground biomass (AGB) and belowground biomass (BGB). Carbon stocks of AGB were higher than those of BGB. It was obvious that carbon stocks of AGB and BGB in Mokelimwaekili forest ecosystem were higher than those of Sombo forest ecosystem. 
Table 3. Available allometric models for estimating above- and below-ground biomass of trees regarding tropical African forests. $D$ is trunk diameter (i.e. diameter at breast height in $\mathrm{cm}$ ); $H$ is total tree height (in $\mathrm{m}$ ); $\rho$ is wood density (in $\mathrm{g} \cdot \mathrm{cm}^{-3}$ ); $l n$ is natural

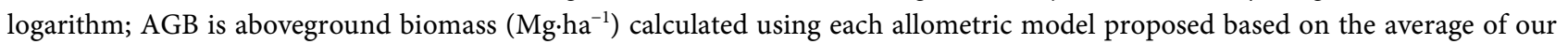
data for each study site; BGB is belowground biomass $\left(\mathrm{Mg} \cdot \mathrm{ha}^{-1}\right)$ calculated using each allometric equation proposed based on our data's mean for Mokelimwaekili and Sombo sites. Average of each parameter applied for Mokelimwaekili site were $\rho=0.6 \mathrm{~g} \cdot \mathrm{cm}^{-3}$, $D=31.12 \mathrm{~cm}$ and $H=17.87 \mathrm{~m}$. Average of each parameter applied for Sombo site were $\rho=0.599 \mathrm{~g} \cdot \mathrm{cm}^{-3}, D=25.95 \mathrm{~cm}$ and $H=$ $13.21 \mathrm{~m}$.

\begin{tabular}{|c|c|c|c|c|c|c|c|}
\hline \multirow[b]{2}{*}{ Source } & \multirow[b]{2}{*}{ Location } & \multirow[b]{2}{*}{ Predictor } & \multirow[b]{2}{*}{ Allometric equation } & \multicolumn{2}{|c|}{$\begin{array}{l}\text { Mokelimwaekili } \\
\text { (Old-growth } \\
\text { forest) }\end{array}$} & \multicolumn{2}{|c|}{$\begin{array}{c}\text { Sombo } \\
\text { (Selective } \\
\text { logging forest) }\end{array}$} \\
\hline & & & & AGB & BGB & AGB & BGB \\
\hline [11] & Gabon & $\mathrm{D}, \mathrm{H}, \rho$ & $A G B=\left[-2.5680+0.9517 \times \ln \left(D^{2} H\right)+1.1891 \times \ln (\rho)\right]$ & 6.1 & $1.2([35])$ & 5.4 & $1.1([35])$ \\
\hline$[18]$ & Pantropical & $\mathrm{D}, \mathrm{H}, \rho$ & $A G B=0.0673 \times\left[\left(\rho D^{2} H\right)\right]^{0.976}$ & 559.7 & $\begin{array}{l}131.5 \\
([35])\end{array}$ & 291.8 & $\begin{array}{c}68.5 \\
([35])\end{array}$ \\
\hline [32] & Cameroon & $\mathrm{D}, \rho$ & $A G B=\exp (-1.862+2.402 \times \ln (D)-0.341 \times \ln (\rho))$ & 713.3 & & 461.3 & \\
\hline$[20]$ & Cameroon & $\mathrm{D}$ & $A G B=\exp (-2.331+2.596 \times \ln (D))$ & 730.4 & & 455.3 & \\
\hline$[34]$ & Madagascar & $\mathrm{D}, \mathrm{H}, \rho$ & $A G B=\exp \left(-2.108+0.908 \times \ln \left(\rho D^{2} H\right)\right)$ & 538.7 & & 293.7 & \\
\hline$[43]$ & Ghana & $\mathrm{D}, \mathrm{H}, \rho$ & $A G B=3.47 \times 10^{-3}+0.02 \times \rho D^{2} H$ & 207.6 & & 106.4 & \\
\hline$[10]$ & DR Congo & $\mathrm{D}$ & $A G B=(36.3576-31.6591 \times \exp (-0.0221 \times D))$ & 20.4 & & 18.5 & \\
\hline [8] & Africa & $\mathrm{D}, \mathrm{H}, \rho$ & $A G B=-2.9205+0.9894 \times \ln \left(D^{2} \rho H\right)$ & 6.2 & & 5.5 & \\
\hline$[45]$ & Tanzania & $\mathrm{D}, \mathrm{H}$ & $A G B=0.076 \times D^{2.2046} \times H^{0.4918}$ & 613.9 & & 354.2 & \\
\hline$[45]$ & Tanzania & $\mathrm{D}, \mathrm{H}$ & $B G B=0.176 \times D^{1.784} \times H^{0.343}$ & & 218 & & 142 \\
\hline$[47]$ & Mozambique & $\mathrm{D}$ & $A G B=\exp (2.601 \times \log (D)-3.629)$ & 1.2 & & 1 & \\
\hline$[47]$ & Mozambique & $\mathrm{D}$ & $B G B=\exp (2.262 \times \log (D)-3.370)$ & & 1 & & 0.8 \\
\hline$[5]$ & DR Congo & $\mathrm{D}, \mathrm{H}, \rho$ & $A G B=1.603 \times \rho\left(D^{2} H\right)^{0.657}$ & 697.7 & & 449.8 & \\
\hline$[30]$ & Benin & $\mathrm{D}, \mathrm{H}$ & $A G B=\exp (-2.63+1.99 \times \ln (D)+0.67 \times \ln (H))$ & 465.4 & & 264.6 & \\
\hline$[32]$ & Cameroon & $\mathrm{D}, \mathrm{H}, \rho$ & $A G B=\exp \left(-2.436+0.139 \times[\ln (D)]^{2}+0.737 \times \ln \left(D^{2} H\right)+0.279 \times \ln (\rho)\right)$ & 521.4 & & 269.2 & \\
\hline
\end{tabular}

\subsection{Diameter-Height Allometry Variation}

Stand-specific height-diameter regression model developed by [18] with three predictors including tree height, tree trunk diameter and wood density were applied to each forest site (Mokelimwaekili and Sombo forests). The use of both DBH and height significantly improved the accuracy of estimates [31]. All trees known to be broken damaged or leaning more than $10 \%$ was excluded from the analysis. Weibull, Chapman-Richards, logistic, power and two- and three-parameter exponential models were compared. The optimal model was selected based on the Akaike Information Criterion and the residual standard error, and was further used to determine tree heights for aboveground carbon stock estimation. This growth within the crown may be related to the need to produce new leaves to compensate for leaves lost owing to the longevity of the lower crown. These results explain the different time trajectories in $D: H$ relationships among individual trees, and also the long-term changes in the $D: H$ relationships. The view 
that a rise in the crown base is strongly related to leaf turnover helps to interpret $D: H$ relationships. Figure 5 shows Mokelimwaekili and Sombo sites' relationship about tree trunk diameter at breast height. Figure 4(d) showed the average Diameter-height distribution of trees in Sombo forest. Figure 5 shows that trees trunk diameter and trees height in Mokelimwaekili were higher than those of Sombo.

Our database has been applied on the [28] moist biomass equation to estimate biomass (aboveground biomass). AGB with trunk diameter and wood density $\left(\mathrm{Mg} \cdot \mathrm{ha}^{-1}\right)$ has been calculated as a function of tree diameter and wood specific gravity $\left(\rho, \mathrm{g} \cdot \mathrm{cm}^{-3}\right)$ and estimated height. Height has been calculated using the [41] Weibull ([8], three-parameter) model at region level. Region classification based on [41]. The result shows that an important mean of aboveground bio-

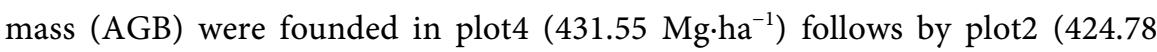
$\mathrm{Mg} \cdot \mathrm{ha}^{-1}$ ), plot1 (378.40), plot7 (331.94 Mg.ha ${ }^{-1}$ ), plot3 (322.89 Mg.ha ${ }^{-1}$ ), plot8 $\left(306.38 \mathrm{Mg} \cdot \mathrm{ha}^{-1}\right)$, plot5 (296.68 $\left.\mathrm{Mg} \cdot \mathrm{ha}^{-1}\right)$ and at a low AGB in plot6 (240.85 $\left.\mathrm{Mg} \cdot \mathrm{ha}^{-1}\right)$.

However, in Table 3 we compared a number of statistical models commonly used to estimate aboveground biomass and belowground biomass in the forestry literature. A large number of regression models have already been published, and we only selected a limited subset of these, based on their mathematical simplicity and their applied relevance. Typical estimation of aboveground biomass

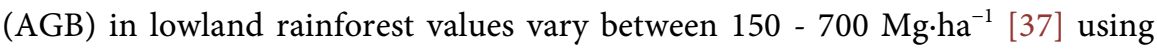
the calculation based on the models developed by [8], and by [18] and as asserted by Afritron network (see http://www.afritron.org).

\section{Discussion}

Mean aboveground biomass (AGB) were $559.7 \mathrm{Mg} \cdot \mathrm{ha}^{-1}$ and $291.9 \mathrm{Mg} \cdot \mathrm{ha}^{-1}$ belong to Mokelimwaekili and Sombo respectively. Average belowground biomass

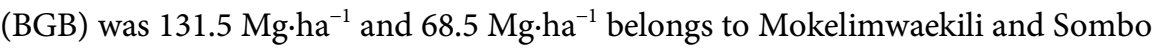
respectively (Table 3). We founded that in this study, Mokelimwaekili recorded an important mean of AGB compared with Sombo. But more trees have been recorded in Sombo (733 trees) than Mokelimwaekili (607 trees) as mentioned in Table 1. It's important to mention that Mokelimwaekili is an old-growth forest and Sombo is a selective logging forest. The difference about this biomass amount may be related to different forest type and also to climatic determinism which is more humid and favorable in old-growth forest where the Mokelimwaekili (Figure 1(a)) ecosystem is located.

Although many authors have suggested both $\ln$-normal and $\ln -\ln$ models as the most accurate for explaining allometric relationships, it is worth noting that the use of the power model is supported by growth that assumes a constant scaling rate across ontogenies. Comparing five forms of allometric relationships between tree diameter at breast height and tree height, [41] found $\ln$-ln models sufficient for normalizing the data and suitable to use. In a recent study, [14] 
compared three sets of diameter-height allometric equations using a compiled data set from moist African forests and found the Mitscherlich model [10] most suitable. In the present case, we found that a high variance of height (up to 96.1\%) was explained by trunk diameter when applying the $\ln$-ln model. More interestingly, we found that the diameter-height relationship varied among studied species, among studied plot and between studied sites [41], as the slope in the Triplochiton scleroxylon K. Schum diameter-height relationship was significantly higher than those for the other species. This can be explained by the fact that Triplochiton scleroxylon K. Schum., also called by Ayous (i.e., Family: Sterculiaceae, Max DBH: $160.4 \mathrm{~cm}$, Max height: $45.2 \mathrm{~m}$, Pygmy name: Molossi) is a typical pioneer tree species in these forests (Mokelimwaekili and Sombo), even though Entandrophragma angolense (Welw.ex C. DC.) C. DC. (i.e., Max DBH: 150 cm, Max height: 45 m, Commercial name: Sapeli, Family: Meliaceae, Pygmy name: Diboyo), and Milicia excelsa (Welw.) C.C. Berg (i.e., Max DBH: $130 \mathrm{~cm}$, Max height: 43 m, Commercial name: Iroko, Family: Moraceae, Pygmy name: Dangui) are also relatively more light-demanding than most other forest canopy species. This result first means that the height at a given diameter varied among studied species, studied plots and studied site (Figure 3(e) and Figure $4(\mathrm{~d}))$, probably as a result of species-specific architectural and physiological structures [6] or a consequence of competition as asserted in Figure 3. It is also possible that the diameter-height relationship varies within the same species as a result of the influence of environmental conditions on growth rate (e.g. growing in a relatively closed canopy versus growing up through a canopy gap), as shown by [31]. From a biological viewpoint, this result means that tree height would be a determinant variable in biomass models, because species and individuals with the same trunk diameter but different height are expected to have different biomass allometry. Therefore, accurate measurement and prediction of tree height are important for improving the predictive abilities of biomass equations, as well as the estimation of stand biomass and carbon stock in forest ecosystems [14] [31].

For instance, the use of a common equation to predict the branch biomass and to further up-scale the biomass from branch to tree level implied that the tree biomass values were not exactly independent, and as such, the prediction error should be accounted for, especially by addressing the issue of error propagation from the branch to the tree level [31]. The study by [8] has recently expanded the frequently used pan-tropical [28] equation with African data from Congo basin. The robustness and accuracy of this equation has been noted for some African regions [10] [29] with its strength lying in the large sample size of tropical trees compared with the other equations. Nevertheless, the use of pantropical equations [10] [28] in unstudied areas needs to be done with care as it could produce systematic errors in carbon stock estimates, specifically if not all variables, namely diameter, wood density and tree height, are accounted for. The use of these equations in Africa faced a lot of criticism since no data from Africa 
were used to develop these equations. Also, often, independent sample data are not used to evaluate the models in the studied area.

Recent studies [2] [5] [11] [20] [32] [43] [44] [45] were local, or country-specific. The study of [32] added to locally collected data, other data from South America and tropical Asia to develop pan-tropical allometric equations. Since most of the data came from other locations outside Africa, the accuracy of these equations to measure tropical forest biomass in Africa was still questionable. The recent study of [18] used data collected in Africa, Asia and South America to develop a unique allometric equation valid in all ecosystems. Although they recognized that there was a site effect, the study assumed that the site effect and forest types could be negligible if diameter, height and wood density are included and the biomass can be approximated by a single equation. The combination of diameter, height and wood density in the models provided the best estimator for aboveground biomass. To generate carbon credits under the REDD (Reducing Emissions from Deforestation and forest Degradation) program [46] [47], accurate estimates of forest carbon stocks are needed. Carbon accounting efforts have focused on carbon stocks in aboveground biomass (AGB), also in belowground biomass (BGB).

\section{Conclusion}

There were confidence intervals around the mean aboveground biomass estimation for all studied sites (Mokelimwaekili and Sombo, respectively old-growth and selective logging forests) due to variability in aboveground biomass among plots. Equations integrating diameter, height and wood density provided the best estimators for estimation of total biomass in the two forest types and this study therefore suggests for biomass and carbon estimation of trees to always combine these variables whenever it is possible. For height estimations, the use of density as additional independent variable to tree diameter improved the quality of estimations, and this study recommends combining these variables when using these equations or when developing new tree height equations for tropical mixed forests. The choice of appropriate allometric models is crucial for reducing uncertainties in natural forest biomass estimates. The non-destructive sampling approach used here was dictated by the protected status of the forests, and could serve as an example for other places where trees are protected or where the wood resource is scarce. Nevertheless, the application of this non-destructive method requires an up-scaling of the biomass from branch to tree level, which is tied with some uncertainties. Therefore, specific future studies need to be undertaken in Republic of Congo's forests by comparing non-destructive with some destructive preferably approaches targeting species that are not nationally protected. Outcomes of this research would also help to measure the level of accuracy attained with the application of non-destructive sampling, and thereby contribute to improve the reliability of the biomass stocks in natural forests for carbon economic initiatives. Finally, the present study on biomass and carbon stocks of 
trees in Ipendja terra firme mixed evergreen tropical forest from Likouala Department (Northern Republic of Congo) will allow Republic of Congo to receive the carbon credit under the CN-REDD Congo's national strategy.

\section{Acknowledgements}

This study was supported by the National Key Research and Development Project of China (2017YFD0600106). The authors would like to thank China Scholarship Council (see http://www.csc.edu.cn) and Beijing Forestry University (see http://www.bjfu.edu.cn) for supporting this work. We greatly thank Seraphin Bikoumou, Martial Fomekong Tsakeu, Ghislain Teufack Sonna, Meroli Bokouaye, Freddy Iyoki, Wilfrid Bandakoulou, Roger Bassoukaka, Hermann, Jean and Benoit from Thanry-Congo logging company (STC) for them technical assistance during forest inventory data period at Ipendja forest management unit (UFA). Our warm thanks are to Republic of Congo's Ministry of Forest Economy and Sustainable Development, CN-REDD, and Thanry-Congo logging company (STC, Vic-wood Group) for providing facilities about field measurements in Ipendja forest (Likouala Department, Northern Republic of Congo). Thanks are extended to Georges Claver Boundzanga from Republic of Congo's Ministry of Forest Economy and Sustainable Development for his valuable contribution regarding this study. Different anonymous referees have provided substantial contribution and the authors address to them their heartfelt thanks.

\section{Conflicts of Interest}

The authors declare no conflict of interest.

\section{Additional Information}

Supplementary material related to this paper is available online at http://www.scirp.org/journal/oje/.

\section{References}

[1] Lewis, S.L., Sonke, B., Sunderland, T., Begne, S.K., Lopez-Gonzalez, G., van der Heijden, G.M.F., Phillips, O.L., Affum-Baffoe, K., Baker, T.R., Banin, L., Willcock, S., Woell, H. and Zemagho, L. (2013) Above-Ground Biomass and Structure of 260 African Tropical Forests. Philosophical Transactions of the Royal Society: Biological Sciences, 368, Article ID: 20120295. https://doi.org/10.1098/rstb.2012.0295

[2] Basuki, T.M., van Laake, P.E., Skidmore, A.K. and Hussin, Y.A. (2009) Allometric Equations for Estimating the Above-Ground Biomass in Tropical Lowland Dipterocarp Forests. Forest Ecology and Management, 257, 1684-1694. https://doi.org/10.1016/j.foreco.2009.01.027

[3] Brown, S. (1997) Estimating Biomass and Biomass Change of Tropical Forests: A Primer. FAO Forestry Paper 134, Food and Agriculture Organization of the United Nations, Rome, Italy.

[4] Djomo, A.N., Picard, N., Fayolle, A., Henry, M., Ngomanda, A., Ploton, P., McLellan, J., Saborowski, J., Adamou, I. and Lejeune, P. (2016) Tree Allometry for Estimation of Carbon Stocks in African Tropical Forests. Forestry, 89, 446-455. 
https://doi.org/10.1093/forestry/cpw025

[5] Ebuy, J., Lokombe, J.P., Ponette, Q., Sonwa, D. and Picard, N. (2011) Allometric Equation for Predicting Aboveground Biomass of Three Tree Species. Journal of Tropical Forest Science, 23, 125-132.

[6] Ekoungoulou, R., Nzala, D., Liu, X.D. and Niu, S.K. (2017) Ecological and Structural Analyses of Trees in an Evergreen Lowland Congo Basin Forest. International Journal of Biology, 10, 31-43. https://doi.org/10.5539/ijb.v10n1p31

[7] FAO (2016) State of the World's Forests. Forests and Agriculture: Land-Use Challenges and Opportunities. Food and Agriculture Organization of the United Nations, Rome, Italy.

[8] Feldpausch, T.R., Lloyd, J., Lewis, S.L., Brienen, R.J.W., Gloor, M., Monteagudo Mendoza, A., Lopez-Gonzalez, G., Banin, L., Abu Salim, K., Affum-Baffoe, K., Alexiades, M., Almeida, S., Amaral, I., Andrade, A., Aragao, L.E.O.C., Araujo Murakami, A., Arets, E.J.M.M., Arroyo, L., Silva-Espejo, J.E., Silveira, M., Sonke, B., Stropp, J., Taedoumg, H.E., Tan, S., ter Steege, H., Terborgh, J., Torello-Raventos, M., van der Heijden, G.M.F., Vasquez, R., Vilanova, E., Vos, V.A., White, L., Willcock, S., Woell, H. and Phillips, O.L. (2012) Tree Height Integrated into Pantropical Biomass Forest Estimates. Biogeosciences, 9, 3381-3403.

https://doi.org/10.5194/bg-9-3381-2012

[9] IPCC (2006) Guidelines for National Greenhouse Gas Inventories. Institute for Global Environmental Strategies, Intergovernmental Panel on Climate Change, Hayama, Japan.

[10] Kearsley, E., De-Haulleville, T., Hufkens, K., Kidimbu, A., Toirambe, B., Baert, G., Huygens, D., Kebede, Y., Defourny, P., Bogaert, J., Beeckman, H., Steppe, K., Boeckx, P. and Verbeeck H. (2013) Conventional Tree Height-Diameter Relationships Significantly Overestimate Aboveground Carbon Stocks in the Central Congo Basin. Nature Communications, 4, Article No. 2269. https://doi.org/10.1038/ncomms3269

[11] Ngomanda, A., Obiang, N.L.E, Lebamba, J., Mavouroulou, Q.M., Gomat, H., Mankou, G.S., Loumeto, J., Iponga, D.M., Ditsouga, F.K., Koumba, R.Z., Botsika-Bobe, K.H., Okouyi, C.M., Nyangadouma, R., Lepengue, N., Mbatchi, B. and Picard, N. (2014) Site-Specific versus Pantropical Allometric Equations: Which Option to Estimate the Biomass of A Moist Central African Forest? Forest Ecology and Management, 312, 1-9. https://doi.org/10.1016/j.foreco.2013.10.029

[12] Picard, N., Bosela, F.B. and Rossi, V. (2014) Reducing the Error in Biomass Estimates Strongly Depends on Model Selection. Annals of Forest Science, 72, 811-823. https://doi.org/10.1007/s13595-014-0434-9

[13] Ekoungoulou, R., Liu, X.D., Ifo, S.A., Loumeto, J.J. and Folega, F. (2014) Carbon Stock Estimation in Secondary Forest and Gallery Forest of Congo Using Allometric Equations. International Journal of Scientific and Technology Research, 3, 465-474.

[14] Picard, N., Rutishauser, E., Ploton, P., Ngomanda, A. and Henry, M. (2015) Should Tree Biomass Allometry Be Restricted to Power Models? Forest Ecology and Management, 353, 156-163. https://doi.org/10.1016/j.foreco.2015.05.035

[15] Ploton, P., Barbier, N., Takoudjou Momo, T.S, Rejou-Mechain, M., Bosela, B.F., Chuyong, G., Dauby, G., Droissart, V., Fayolle, A., Goodman, C.S., Henry, M., Thomas, D., Zebaze, D., Couteron, P., Berger, U. and Pelissier, R. (2016) Closing a Gap in Tropical Forest Biomass Estimation: Taking Crown Mass Variation into Account in Pantropical Allometries. Biogeosciences, 13, 1571-1585.

https://doi.org/10.5194/bg-13-1571-2016 
[16] Ramananantoandro, T., Rafidimanantsoa, H.P. and Ramanakoto, M.F. (2015) Forest Aboveground Biomass Estimates in a Tropical Rainforest in Madagascar: New Insights from the Use of Wood Specific Gravity Data. Journal of Forestry Research, 26, 47-55. https://doi.org/10.1007/s11676-015-0029-9

[17] Talbot, J., Lewis, L.S., Lopez-Gonzalez, G., Brienen, J.W.R., et al. (2014) Methods to Estimate Aboveground Wood Productivity from Long-Term Forest Inventory Plots. Forest Ecology and Management, 320, 30-38. https://doi.org/10.1016/j.foreco.2014.02.021

[18] Chave, J., Rejou-Mechain, M., Burquez, A., Chidumayo, E., Colgan, M.S., Delitti, W.B.C., Duque, A., Eid, T., Fearnside, P.M., Goodman, R.C., Henry, M., Martinez-Yrizar, A., Mugasha, W.A., Muller-Landau, H.C., Mencuccini, M., Nelson, B.W., Ngomanda, A., Nogueira, E.M., Ortiz-Malavassi, E., Pelissier, R., Ploton, P., Ryan, C.M., Saldarriaga, J.G. and Vieilledent, G. (2014) Improved Allometric Models to Estimate the Aboveground Biomass of Tropical Trees. Global Change Biology, 20, 3177-3190. https://doi.org/10.1111/gcb.12629

[19] FAO (2012) State of the World's Forests. Food and Agriculture Organization of the United Nations, Rome, Italy.

[20] Fayolle, A., Doucet, J.L., Gillet, J.F., Bourland, N. and Lejeune, P. (2013) Tree Allometry in Central Africa: Testing the Validity of Pantropical Multispecies Allometric Equations for Estimating Biomass and Carbon Stocks. Forest Ecology and Management, 305, 29-37. https://doi.org/10.1016/j.foreco.2013.05.036

[21] Praciak, A., Pasiecznik, N., Sheil, D., Heist, V.M., Sassen, M., Correia, S.C., Dixon, C., Fyson, E.G., Rushforth, K. and Teeling, C. (2013) The CABI Encyclopedia of Forest Trees. CAB International Publishing, Oxfordshire, UK.

[22] Djomo, N.A. and Chimi, D.C. (2017) Tree Allometric Equations for Estimation of Above, Below and Total Biomass in a Tropical Moist Forest: Case Study with Application to Remote Sensing. Forest Ecology and Management, 391, 184-193. https://doi.org/10.1016/j.foreco.2017.02.022

[23] Fayolle, A., Panzou, G.J.L., Drouet, T., Swaine, M.D., Bauwens, S., Vleminckx, J., Biwole, A., Lejeune, P. and Doucet, J.L. (2016) Taller Trees, Denser Stands and Greater Biomass in Semi-Deciduous than in Evergreen Lowland Central African Forests. Forest Ecology and Management, 374, 42-50.

https://doi.org/10.1016/j.foreco.2016.04.033

[24] Cairns, A.M., Brown, S., Helmer, H.E. and Baumgardner, A.G. (1997) Root Biomass Allocation in the World's Upland Forests. Oecologia, 111, 1-11. https://doi.org/10.1007/s004420050201

[25] Ekoungoulou, R., Liu, X.D., Loumeto, J.J. and Ifo, S.A. (2014) Tree Above- and Below-Ground Biomass Allometries for Carbon Stocks Estimation in Secondary Forest of Congo. Journal of Environmental Science, Toxicology and Food Technology, 8, 9-20.

[26] Ekoungoulou, R. (2014) Carbon Stocks Evaluation in Tropical Forest, Congo. Carbon Stocks in Forest Ecosystems. Lambert Academic Publishing, Saarbrucken, Germany.

[27] Ekoungoulou, R., Liu, X.D., Loumeto, J.J., Ifo, S.A., Bocko, Y.E., Koula, F.E. and Niu, S.K. (2014) Tree Allometry in Tropical Forest of Congo for Carbon Stocks Estimation in Above-Ground Biomass. Open Journal of Forestry, 4, 481-491. https://doi.org/10.4236/ojf.2014.45052

[28] Chave, J., Andalo, C., Brown, S., Cairns, M.A., Chambers, J.Q., Eamus, D., Folster, H., Fromard, F., Higuchi, N., Kira, T., Lescure, J.P., Nelson, B.W., Ogawa, H., Puig, 
H., Riera, B. and Yamakura, T. (2005) Tree Allometry and Improved Estimation of Carbon Stocks and Balance in Tropical Forests. Oecologia, 145, 87-99. https://doi.org/10.1007/s00442-005-0100-x

[29] Ekoungoulou, R., Niu, S.K., Loumeto, J.J., Ifo, S.A., Bocko, Y.E., Mikieleko, F.E.K., Guiekisse, E.D.M., Senou, H. and Liu, X.D. (2015) Evaluating the Carbon Stock in Above- and Below-Ground Biomass in a Moist Central African Forest. Applied Ecology and Environmental Sciences, 3, 51-59.

[30] Goussanou, C.A., Guendehou, S., Assogdadjo, A.E., Kaire, M., Sinsin, B. and Cuni-Sanchez, A. (2016) Specific and Generic Stem Biomass and Volume Models of Trees in a West Africa Tropical Semi-Deciduous Forest. Silva Fennica, 50, Article ID: 1474 . https://doi.org/10.14214/sf.1474

[31] Mensah, S., Veldtman, R. and Seifert, T. (2017) Allometric Models for Height and Aboveground Biomass of Dominant Tree Species in South African Mistbelt Forests. Southern Forests. A Journal of Forest Science, 79, 19-30. https://doi.org/10.2989/20702620.2016.1225187

[32] Djomo, A.N., Ibrahima, A., Saborowski, J. and Gravenhorst, G. (2010) Allometric Equations for Biomass Estimations in Cameroon and Pan Moist Tropical Equations Including Biomass Data from Africa. Forest Ecology and Management, 260, 1873-1885. https://doi.org/10.1016/j.foreco.2010.08.034

[33] Deans, J.D., Moran, J. and Grace, J. (1996) Biomass Relationships for Tree Species in Regenerating Semi-Deciduous Tropical Moist Forest in Cameroon. Forest Ecology and Management, 88, 215-225. https://doi.org/10.1016/S0378-1127(96)03843-1

[34] Vieilledent, G., Vaudry, R., Andriamanohisoa, S.F.D., Rakotonarivo, O.S., Randrianasolo, H.Z., Razafindrabe, H.N., Rakotoarivony, C.B., Ebeling, J. and Rasamoelina, M. (2012) A Universal Approach to Estimate Biomass and Carbon Stock in Tropical Forests Using Generic Allometric Models. Ecological Applications, 22, 572-583. https://doi.org/10.1890/11-0039.1

[35] Mokany, K., Raison, R.J. and Prokushkin, A.S. (2006) Critical Analysis of Root: Shoot Ratios in Terrestrial Biomes. Global Change Biology, 12, 84-96. https://doi.org/10.1111/j.1365-2486.2005.001043.x

[36] STC (2016) Annual Report of Thanry-Congo Logging Company. Vicwood Group, Ipendja, Republic of Congo. (In French)

[37] Lopez-Gonzalez, G., Lewis, S.L., Burkitt, M. and Phillips, O.L. (2011) ForestPlots.net: A Web Application and Research Tool to Manage and Analyse Tropical Forest Plot Data. Journal of Vegetation Science, 22, 610-613. https://doi.org/10.1111/j.1654-1103.2011.01312.x

[38] ANAC (2016) Annual Report on Republic of Congo's Meteorological National Situation. National Agency of Congo's Civil Aviation, Brazzaville, Congo. (In French)

[39] Chave, J., Coomes, D.A., Jansen, S., Lewis, S.L., Swenson, N.G. and Zanne, A.E. (2009) Towards a Worldwide Wood Economics Spectrum. Ecology Letters, 12, 351-366. https://doi.org/10.1111/j.1461-0248.2009.01285.x

[40] Zanne, A.E., Lopez-Gonzalez, G., Coomes, D.A., Ilic, J., Jansen, S., Lewis, S.L., Miller, R.B., Swenson, N.G., Wiemann, M.C. and Chave, J. (2009) Data from: Towards a Worldwide Wood Economics Spectrum. Dryad Digital Repository.

[41] Feldpausch, T.R., Banin, L., Phillips, O.L., Baker, T.R., Lewis, S.L., Quesada, C.A., Affum-Baffoe, K., Arets, E., Berry, N.J., Bird, M., et al. (2011) Height-Diameter Allometry of Tropical Forest Trees. Biogeosciences, 8, 1081-1106. https://doi.org/10.5194/bg-8-1081-2011

[42] Hammer, O., Harper, D.A.T. and Ryan, P.D. (2001) PAST: Paleontological Statistics 
Software Package for Education and Data Analysis. Palaeontologia Electronica, 4, 1-9.

[43] Henry, M., Besnard, A., Asante, W.A., Eshun, J., Adu-Bredu, S., Valentini, R., Bernoux, M. and Saint-André, L. (2010) Wood Density, Phytomass Variations within and among Trees, and Allometric Equations in a Tropical Rainforest of Africa. For est Ecology and Management, 260, 1375-1388. https://doi.org/10.1016/j.foreco.2010.07.040

[44] Banin, L., Feldpausch, T.R., Phillips, O.L., Baker, T.R., Lloyd, J., Affum-Baffoe, K., Arets, E.J.M.M., Berry, N.J., Bradford, M., Brienen, R.J.W., Davies, S., Drescher, M., Higuchi, N., Hilbert, D.W., Hladik, A., Iida, Y., Salim, K.A., Kassim, A.R., King, D.A., Lopez-Gonzalez, G., Metcalfe, D., Nilus, R., Peh, K.S.H., Reitsma, J.M., Sonke, B., Taedoumg, H., Tan, S., White, L., Woll, H. and Lewis, S.L. (2012) What Controls Tropical Forest Architecture? Testing Environmental, Structural and Floristic Drivers. Global Ecology and Biogeography, 21, 1179-1190. https://doi.org/10.1111/j.1466-8238.2012.00778.x

[45] Mugasha, W.A., Eid, T., Bollandsas, O.M., Malimbwi, R.E., Chamshama, S.A.O., Zahabu, E. and Katani, J.Z. (2013) Allometric Models for Prediction of Above- and Belowground Biomass of Trees in the Miombo Woodlands of Tanzania. Forest Ecology and Management, 310, 87-101. https://doi.org/10.1016/j.foreco.2013.08.003

[46] Ekoungoulou, R., Folega, F., Mukete, B., Ifo, S.A., Loumeto, J.J., Liu, X.D. and Niu S.K. (2018) Assessing the Effectiveness of Protected Areas on Floristic Diversity in Tropical Forests. Applied Ecology and Environmental Research, 16, 837-853.

[47] Ryan, C.M., Williams, M. and Grace, J. (2011) Above- and Belowground Carbon Stocks in a Miombo Woodland Landscape of Mozambique. Biotropica, 43, 423-432. https://doi.org/10.1111/j.1744-7429.2010.00713.x 